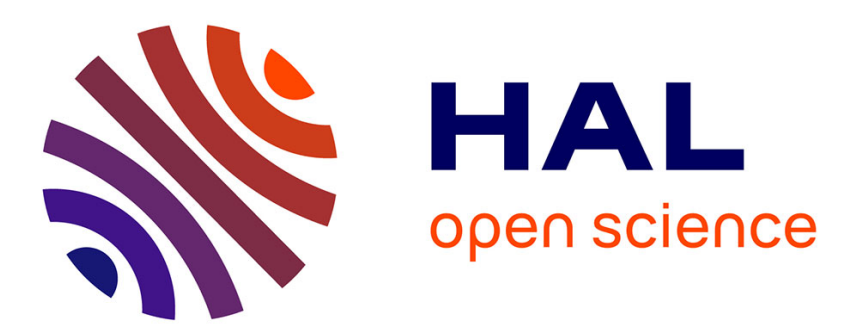

\title{
Impact of extreme environmental conditions: Foraging behaviour and trophic ecology responses of a diving seabird, the common diving petrel
}

Aymeric Fromant, Karine Delord, Charles-André Bost, Yonina Eizenberg, Jonathan Botha, Yves Cherel, Paco Bustamante, Brett Gardner, Maud Brault-Favrou, Arnaud Lec'Hvien, et al.

\section{To cite this version:}

Aymeric Fromant, Karine Delord, Charles-André Bost, Yonina Eizenberg, Jonathan Botha, et al.. Impact of extreme environmental conditions: Foraging behaviour and trophic ecology responses of a diving seabird, the common diving petrel. Progress in Oceanography, 2021, 198, pp.102676. 10.1016/j.pocean.2021.102676 . hal-03342136

\section{HAL Id: hal-03342136 \\ https://hal.science/hal-03342136}

Submitted on 23 Jan 2022

HAL is a multi-disciplinary open access archive for the deposit and dissemination of scientific research documents, whether they are published or not. The documents may come from teaching and research institutions in France or abroad, or from public or private research centers.
L'archive ouverte pluridisciplinaire HAL, est destinée au dépôt et à la diffusion de documents scientifiques de niveau recherche, publiés ou non, émanant des établissements d'enseignement et de recherche français ou étrangers, des laboratoires publics ou privés. 


\section{Impact of extreme environmental conditions: foraging behaviour and trophic ecology responses of a diving seabird, the common diving petrel}

Aymeric Fromant ${ }^{1,2}$, Karine Delord ${ }^{2}$, Charles-André Bost ${ }^{2}$, Yonina H. Eizenberg ${ }^{1,2}$, Jonathan A. Botha $^{3}$, Yves Cherel ${ }^{2}$, Paco Bustamante ${ }^{4,5}$, Brett R. Gardner ${ }^{6}$, Maud Brault-Favrou ${ }^{4}$, Arnaud Lec'hvien $^{1}$, John P.Y. Arnould ${ }^{1}$

${ }^{1}$ School of Life and Environmental Sciences, Deakin University, 221 Burwood Hwy, Burwood, VIC 3125, Australia

${ }^{2}$ Centre d'Etudes Biologiques de Chizé (CEBC), UMR 7372 CNRS - La Rochelle Université, 79360 Villiers-en-Bois, France

${ }^{3}$ Marine Apex Predator Research Unit (MAPRU), Department of Zoology and Institute for Coastal and Marine Research, Nelson Mandela University, Port Elizabeth 6031, South Africa

${ }^{4}$ Littoral Environnement et Sociétés (LIENSs), UMR 7266 - La Rochelle Université, 2 rue Olympe de Gouges, 17000 La Rochelle, France

${ }^{5}$ Institut Universitaire de France (IUF), 1 rue Descartes 75005 Paris, France

${ }^{6}$ Werribee Open Range Zoo, Zoos Victoria, K-Road, Werribee Park Precinct, 3030 VIC, Australia

Correspondence: Aymeric Fromant afromant@deakin.edu.au 
Abstract: The reproductive success of birds is strongly driven by environmental conditions at different time scales. Thus, during periods of low food availability, breeding success is constrained by the ability of adults to adapt their foraging effort and feeding behaviour to maintain regular incubation shifts and chick provisioning. However, while large seabirds can buffer disruptions in prey availability, the ecophysiological constraints of smaller species may limit their behavioural flexibility. By combining information on at-sea movements, foraging habitat, trophic niche, and breeding success, this study evaluated the effects of intense variability in oceanographic conditions on common diving petrels (Pelecanoides urinatrix) at the northern extent of their range in southeastern Australia during four consecutive breeding seasons. Unusually low breeding success (6 and $0 \%$ ) was observed during two years with intense heatwave events, which were associated with higher foraging effort (foraging trips twice longer) and a substantial shift in trophic niche (lower blood $\delta^{15} \mathrm{~N}$ values). These findings suggest that common diving petrels in Bass Strait may have reached a critical threshold above which buffering the effects of environmental variability on their reproductive output is not possible. The clear cascading impacts that marine heatwaves have on zooplankton feeders illustrate the profound bottom-up effect induced by such extreme environmental variations, and suggest strong impact on higher-trophic levels. The wide, circumpolar breeding distribution of the common diving petrel, and its high sensitivity to variations in oceanographic conditions, suggest that this species may be a suitable model to study short-term and long-term behavioural responses to the effects of climate change throughout the Southern Ocean.

Keywords: marine heatwave, Pelecanoides urinatrix, inter-annual variation, GPS tracking, stable isotopes, habitat modelling 


\section{Introduction}

Seabirds forage in a patchy and dynamic environment where prey is unevenly distributed (Hunt 1990, Weimerskirch 2007). The variation in physical characteristics of the ocean such as temperature, salinity or currents, strongly influence the distribution and availability of prey which, in turn, determine the foraging behaviour of consumers (Franks 1992). Individuals must be flexible in their foraging behaviour and diet, according to spatio-temporal variations in the abundance and distribution of prey species. Thus, seabirds should adapt their strategy at different time scales (i.e. daily, seasonally or annually) to ensure survival and maximise reproductive output (Haury et al. 1978, Weimerskirch et al. 1993). However, climate change is likely to challenge species, as the anticipated increased alterations in the distribution, abundance and diversity of prey should affect their capacity to cope with environmental variability (Chambers et al. 2011).

Seabirds have been extensively used as ecological indicators of the impacts of environmental variations (Cairn 1992, Piatt et al. 2007, Bost et al. 2008). During periods of low prey abundance, breeding seabirds can adjust their behaviour by increasing their foraging effort and/or adapting their diet (Harding et al. 2007, Cohen et al. 2014). However, behavioural plasticity varies greatly between species and/or populations (Gilmour et al. 2018), and seabirds with less flexible foraging strategies or capabilities may not cope with drastic environmental variability (Quillfeldt \& Masello 2013, Jakubas et al. 2020). Due to their relatively easier access for data collection, the majority of studies have focused on large iconic species, resulting in knowledge being mostly restricted to species of higher trophic level, broad diet and/or large foraging range (Chiaradia et al. 2010, Price et al. 2020). Consequently, our understanding of the links between seabird parameters and variation in oceanographic conditions is limited (Grémillet \& Charmantier 2010), with little information available for species feeding locally on low trophic level prey. 
This is exemplified by small pursuit-diving seabirds with high flight costs that might be less able to buffer the consequences of reduced prey availability and longer foraging trips (Elliott et al. 2013). While significant advances have been made in recent years for small Northern Hemisphere alcids (e.g. Grémillet et al. 2012, Amélineau et al. 2019, Jakubas et al. 2020), information on the at-sea movements and foraging behaviour of Southern Hemisphere diving petrels (Procellaridae), and their capacity to adapt, is deficient (Chastel et al. 1995, Cherel et al. 2014). This is of concern considering the wide distribution and large biomass the species comprises (Marchant \& Higgins 1990). For example, the common diving petrel (Pelecanoides urniatrix, study species) is a ubiquitous species of the Southern Ocean estimated to 20-30 million individuals (conservative estimation based on the estimated breeding pairs; Marchant \& Higgins 1990, Brooke 2004) and contributing to $600-900,000$ tonnes of crustacean biomass consumption annually (estimation based on the average consumption per individual; Guinet et al. 1996).

During the breeding season, common diving petrels exhibit a unimodal foraging trip duration strategy. This contrasts with most of the other small Procellariiformes that display a dual foraging strategy by alternating short and long foraging trips (Weimerskirch et al. 1994, Chastel et al. 1995). Across its wide distribution encompassing different environmental conditions, the common diving petrel consistently does short daily trips, during both the incubation (Navarro et al. 2013, Zhang et al. 2018, Dunphy et al. 2020) and chick-rearing periods (Roby 1989, Weimerskirch et al. 1994, Fromant et al. 2020a). This consistent behavioural pattern between populations and across breeding stages could highlight a very high efficiency in foraging and illustrate the species adaptation capacity to different local environments. Conversely, this could indicate a low behavioural plasticity resulting in common diving petrels breeding only where this unimodal foraging behaviour can persist. 
Throughout the species range, common diving petrels show differences in breeding phenology (Fromant et al. 2020b), diet (Reid et al. 1997, Bocher et al. 2000, Fromant et al. 2020c) and diving behaviour (Bocher et al. 2000, Navarro et al. 2014, Dunphy et al. 2015), showing how populations adapt to specific conditions. However, it is uncertain if these variations demonstrate behavioural flexibility at the species and/or population level. In particular, the absence of combined multi-year datasets on the trophic and foraging behaviour at a given locality impedes our understanding of how small, abundant seabirds such as diving petrels adapt to inter-annual environmental changes.

Despite its relatively low primary productivity, Bass Strait, the shallow (50-100 m) continental shelf area between mainland Australia and Tasmania, hosts $60 \%$ of Australian seabirds (Ross et al. 2001). Currents within Bass Strait are complex and dynamic, fluctuating spatially, seasonally and annually, and being influenced by tides, winds and density-driven flows (Sandery \& Kämpf 2007). This region is also one of the most rapidly changing areas of the global ocean, characterised by warming waters and changing currents (Cai et al. 2005, Poloczanska et al. 2007). These ongoing changes are likely to deeply influence the abundance and distribution of cold water zooplanktonic communities (Evans et al. 2020), and could potentially affect zooplanktivorous species such as common diving petrels (Chambers et al. 2011, Evans et al. 2021). In particular, coastal krill (Nyctiphanes australis), the main prey of common diving petrel in Bass Strait (Schumann et al. 2008, Fromant et al. 2020c), exhibits high sensitivity to increased ocean temperatures (Young et al. 1993, Mills et al. 2008). Furthermore, Bass Strait represents the northern extent of the common diving petrel range, and the predicted modification of oceanographic parameters in the region are likely to have a profound effect on this small and geographically isolated population (Schumann et al. 2014). Exploring the foraging and trophic 
ecology of common diving petrels in such a challenging environment will provide valuable information on the extent of its behavioural flexibility and contribute to our understanding of the capacity of small planktonic feeders to buffer contrasted environmental fluctuations.

The present study was conducted over four consecutive years on common diving petrels breeding in Bass Strait. Its aims were to determine: (1) their at-sea movements and habitat use; (2) trophic niche; and 3) inter-annual variation in relation to environmental parameters and reproductive output. Specifically, south-eastern Australia experienced over the last decade successive intense summer marine heatwaves (prolonged periods where ocean temperatures are above the climatological average; Oliver et al. 2017, Perkins-Kirkpatrick et al. 2019). If these extreme rises in sea surface temperature induce major shifts in zooplankton population structure (Evans et al. 2020), the cascading effect that marine heatwaves have on upper trophic levels remains unknown. We predicted that (1) diving petrel trip duration and foraging area would increase in response to the negative effect of marine heatwaves on cold-water zooplanktonic prey; (2) the shifts in prey availability would induce a modification in the birds' trophic niche; and (3) the resultant increased in foraging effort would negatively impacts their breeding success.

\section{Materials and Methods}

\subsection{Study site and animal instrumentation}

The study was conducted during the incubation and chick-rearing periods over four consecutive years (2017-2020) on Kanowna Island (39¹5'S $\left.146^{\circ} 30^{\prime} \mathrm{E}\right)$ in northern Bass Strait, south-eastern Australia. This island is a breeding site for seven seabird species (Fromant et al. 2020d), including 250-500 pairs of common diving petrels (2-4\% of the northern Bass Strait population; Schumann et al. 2014). Some study nests (20-30 per year) were randomly located at 
the start of each breeding season to record the birds' phenology. Control nests (2017: 16; 2018: 66; 2019: 63; 2020: 46) were monitored in early incubation, post-hatching and before fledging to calculate the average reproductive success for the colony (hatching, fledging and breeding success). In addition, during chick-rearing in 2017 , burrows $(n=40)$ were monitored weekly in order to estimate the potential effects of short-term deployments of miniaturized devices on adult body mass, chick growth and breeding success (see Supplementary text; Table S1).

To evaluate the at-sea distribution of common diving petrels during the breeding period, adult breeding birds were equipped with miniature GPS data loggers (nanoFix-GEO, Pathtrack Ltd, Otley, United-Kingdom), attached to two tail feathers using waterproof tape (Tesa 4651; Beiersdorf AG). The total mass of the devices corresponded to $2.25 \pm 0.18 \%$ of body mass (134 \pm $11 \mathrm{~g}$ ) and, thus, was unlikely to have impacted the feeding ecology or breeding performance of individuals (see Supplementary text). During incubation, both partners alternate between $1 \mathrm{~d}$ foraging at sea and $1 \mathrm{~d}$ incubating (Weimerskirch et al. 1994, Zhang et al. 2018), while during chick-rearing (post-brooding stage), both individuals forage at sea during the day and come back to the nest every night to feed the chick (Marchant \& Higgins 1990). Accordingly, during incubation, the study birds were captured in their burrow in the afternoon (corresponding to the end of their shifts) while during the chick-rearing period they were captured at night after feeding the chick.

When individuals were recaptured, a blood sample $(0.2 \mathrm{~mL})$ was collected from the brachial vein for stable isotope analyses and sexing. For all birds, sex was determined by DNA analysis (DNA solutions, Wantirna South, Australia) from either blood or a single body feather. Individuals were weighed ( $\pm 2 \mathrm{~g}$; Pesola), and culmen, tarsus $( \pm 0.1 \mathrm{~mm}$; Vernier calipers $)$ and wing length ( $\pm 1 \mathrm{~mm}$; ruler) were measured. Handling time at deployment (banding, weighing and 
device attachment) and recapture (device removal, measurements, blood and feather sampling) was usually less than 5 min.

\subsection{Environmental data and habitat selection modelling}

Environmental data were used to run two distinct sets of analysis: (1) using sea surface temperature (SST) to explore the variation in foraging ecology and breeding outputs of common diving petrels following summer marine heatwave events. Hereafter, a marine heatwave event is defined as daily SST above the seasonally varying $90^{\text {th }}$ percentile (climatological mean for the period 1981-2010) for more than 5 consecutive days (Oliver et al. 2017, 2021); (2) using dynamic environmental covariates (see details in section 2.2.2.) to describe the habitat selection and determining the physical features explaining the foraging distribution of breeding common diving petrels in Bass Strait.

\subsubsection{Inter-annual variations of oceanographic conditions}

Sea surface temperature has been shown to be the main feature influencing the occurrence and abundance of zooplankton species in south-eastern Australia (Evans et al. 2020, 2021). In particular, the distribution and availability of coastal krill, the main common diving petrel prey in Bass Strait (Schumann et al. 2008, Fromant et al. 2020c), vary substantially between years in relation to SST (Young et al. 1993, Mills et al. 2008). Specifically, summer marine heatwaves with prolonged period of SST above the optimal temperature range of coastal krill $\left(12-18{ }^{\circ} \mathrm{C}\right.$; Sheard 1953) alter the reproduction, survival, and potentially disrupt the availability of this key planktonic species for several months (Ritz \& Hosie 1982, O’Brien 1988). Therefore, for each summer, the duration and intensity 
of periods strictly above the optimal temperature range of coastal krill (>19 ${ }^{\circ} \mathrm{C}$; Sheard 1953$)$ were determined. Monthly averages of SST for the summer period (December-February) were extracted for each $\quad$ gridded $\quad$ cell $\left(0.25^{\circ} \quad\right.$ resolution; dataset MULTIOBS_GLO_PHY_TSUV_3D_MYNRT_015_012 downloaded from Copernicus [http://marine.copernicus.eu/]) within the boundary of the observed home range of common diving petrels in Bass Strait (38.5-41.0 $\left.{ }^{\circ} \mathrm{S}, 144.0-148.0^{\circ} \mathrm{E}\right)$.

\subsubsection{Habitat selection modelling}

To investigate the influence of environmental variables on the at-sea movements and foraging behavior of breeding common diving petrels, habitat selection in relation to habitat availability was determined using a presence-pseudoabsence approach in $\mathrm{R}$ software (Hindell et al. 2020, R Core Team 2020). Specifically, for each real track $(n=187), 20$ pseudo-tracks were simulated by means of a first-order vector autoregressive model fitted using the package availability (Raymond et al. 2016). Simulations were created with constraints on sampling frequency, distances, turning angles and departure/arrival locations to maintain the characteristics of the real tracks. Furthermore, pseudo-tracks were bound by a land mask to ensure that all simulated locations were at sea.

Ten dynamic environmental covariates that have been shown to potentially influence marine predators and their habitat use (Reisinger et al. 2018, Hindell et al. 2020) were incorporated in the habitat selection modelling: SST, sea floor temperature, salinity, mixed layer thickness, sea surface height anomaly, northward velocity, eastward velocity, wave height, wave direction, wave period. Daily environmental data were downloaded from Copernicus 
[http://marine.copernicus.eu/]. Northward and eastward velocities were used to calculate current speed as:

$$
\text { current speed }=\sqrt{\text { northward velocity }{ }^{2}+\text { eastward velocity }}{ }^{2}
$$

In addition, bathymetric data were downloaded from the GEBCO 15-arc second grid [http://www.gebco.net] and used to calculate sea floor slope by means of the terrain function from the raster package. Given that environmental covariates differed substantially in resolution $(0.004$ to $\left.0.083^{\circ}\right)$, all layers were standardized to the coarsest resolution $\left(0.083^{\circ}\right)$ and spatiotemporally matched to each real and pseudo-location using the raster package (Hijmans 2018). Dynamic covariates were averaged for the duration of each track before being matched to each location.

\subsection{Tracking and stable isotope processing and analysis}

\subsubsection{Tracking and spatial analysis}

The GPS data loggers were programmed with a sampling interval of 10 and 5 min during the incubation and chick-rearing periods, respectively. Prior to analysis, land-based points were removed and a speed filter with a threshold at $20 \mathrm{~m} \cdot \mathrm{s}^{-1}$ was applied to remove erroneous locations (Spear \& Ainley 1997). Because of poor satellite reception during intense diving activity, linear interpolation was necessary to correct for unequal sampling frequencies between foraging and commuting periods. For each complete trip (1-7 per individual bird) the following basic parameters were calculated: 1) time of departure and return; 2) trip duration; 3) total horizontal distance travelled; 4) maximum distance from the colony; and 5) bearing at departure and distal location.

For heavily wing-loaded species such as diving petrels, alcids or cormorants, typical foraging trips consist of departing from the colony rapidly with a constant bearing to a particular 
area for foraging, and returning in a direct flight path to the colony (Weimerskirch 2007, Amélineau et al. 2016). Diving petrels forage by diving from the sea surface, which impedes the distinction between foraging and resting behaviors when using GPS only. Foraging/resting (hereafter foraging) areas were defined as areas were instantaneous speed was $\leq 10 \mathrm{~km} \cdot \mathrm{h}^{-1}$, following the method previously used on ecologically similar species (e.g. Amélineau et al. 2016, Jakubas et al. 2020). The remaining positions (speeds $>10 \mathrm{~km} \cdot \mathrm{h}^{-1}$ ) were assumed to represent flying between the colony and the foraging areas or between two feeding areas. In the analysis of the relationship between the proportion of time spent foraging and the total distance travelled, $1 \mathrm{~d}$ trips and $2 \mathrm{~d}$ trips were analyzed separately in order to discount the effect of staying at-sea overnight ( $3 \mathrm{~d}$ trips were not included because of the low sample size). Indeed, in the case of an at-sea overnight stay (common diving petrels do not forage at night; Navarro et al. 2013), the absence of commuting to the colony at the end of the first day, and from the colony at the start of the second day, up weights the proportion of time spent foraging compared to commuting.

Locations identified as foraging were used to generate kernel utilization distribution (UD) estimates using the package adehabitatLT (Calenge 2006). For each year and breeding stage, the $50 \%$ (core foraging area) and 95\% (home range) kernel UD contours were obtained (Worton 1989, Montevecchi et al. 2012). To investigate spatial variation in foraging area, the percentage overlap in foraging distribution between years and breeding stages were estimated using Bhattacharyya's affinity (BA), where 0 indicates no overlap and 1 a complete overlap.

\subsubsection{Isotopic niche analysis}

Stable isotope analyses of carbon $\left(\delta^{13} \mathrm{C}\right)$ and nitrogen $\left(\delta^{15} \mathrm{~N}\right)$ in whole blood were used to investigate temporal change in the common diving petrel trophic niche, reflecting dietary 
integration of approximately two to four weeks (Bearhop et al. 2002). Prior to analyses, samples were freeze-dried, ground to powder and homogenized. The relative abundance of carbon and nitrogen isotopes was determined with a continuous-flow mass spectrometer (Thermo Scientific Delta V Advantage) coupled to an elemental analyser (Thermo Scientific Flash EA 1112). Isotopic results are presented in the $\delta$ notation relative to Vienna PeeBee Belemnite and atmospheric $\mathrm{N}_{2}$ for $\delta^{13} \mathrm{C}$ and $\delta^{15} \mathrm{~N}$, respectively. Replicate measurements of internal laboratory standards (acetanilide) indicate measurement errors $<0.10 \%$ for both $\delta^{13} \mathrm{C}$ and $\delta^{15} \mathrm{~N}$ values. The C:N mass ratios of samples were calculated as the ratio between the mass percentages in carbon and nitrogen. The consistently low C:N values of blood $(<4.0)$ verified that low lipid content did not necessitate lipid extraction (Cherel et al. 2005a). The isotopic niche position and width was compared between years and breeding stages using the ellipse area-based metrics of the SIBER package (Jackson et al. 2011). The isotopic niche was estimated by the $40 \%$ standard ellipse area corrected for small sample size $(\mathrm{SEA})$, the Bayesian standard ellipses areas $\left(\mathrm{SEA}_{\mathrm{B}}\right)$ on $10^{5}$ replicates was used to measure the overlap of the isotopic niches between each breeding stage, and the total area of the convex hull (TA) to provide an indication of the niche width (Jackson et al. 2011).

\subsection{Statistical analyses}

To examine seasonal and inter-annual differences in SST, a one-way ANOVA and Tukey's post-hoc analysis were used. Habitat selection was assessed using boosted regression trees (BRT) (Friedman 2001) to determine the importance of each environmental covariate on the probability of habitat used in relation to availability. To ensure that individuals contributed equally to the analysis, modelling was restricted to the first foraging trip of each individual. Prior to analysis, collinearity between predictor effects was assessed and, if correlations where $>0.6$, the 
environmental covariate with the highest average correlations was excluded from the model (sea floor temperature, wave height). The BRT were fitted using the dismo package (Hijmans et al. 2016) and locations were modelled as a binomial response, where all real locations were represented by 1 and all pseudo-locations were represented by 0 . The BRT were fitted with a tree complexity of 5 and total of 6450 trees were fitted at a learning rate of 0.05 (Elith et al. 2008). Model performance was evaluated using 10-fold cross validation and represented by the area under the receiver operating characteristic curve (AUC).

Effects on foraging parameters (i.e. time of departure and return, trip duration, total horizontal distance travelled, maximum distance from the colony, and bearing at departure and distal location) were investigated generating multiple Generalized Linear Mixed Models (GLMM) using the package $\operatorname{glmm} A D M B$ (Bolker et al. 2012). Year, breeding stage and sex were considered as fixed effects, and individual was added as a random effect, with a Gaussian family. Models were ranked based on their Akaike's Information Criterion (AIC) and were checked to ensure normality and homoscedasticity of residuals (Zuur et al. 2010) before further statistical analysis. Data normality and homogeneity of the variance were assessed with Shapiro-Wilk and Bartlett tests, respectively. Post-hoc analyses were conducted using pairwise comparisons of least-squares means between years, breeding stages and sex (package emmeans; Lenth 2020) with the Tukey method for p-value adjustment. The variation between years and stages in the trip orientation (bearing at departure and at distal location) was investigated by calculating the angular difference (Rao's spacing test, alpha $=0.05$; package circular; Lund et al. 2017). Differences between years and breeding stages $\delta^{13} \mathrm{C}$ and $\delta^{15} \mathrm{~N}$ values were tested by using 2-way semi-parametric permutation multivariate analyses of variance test (PERMANOVA) on the Euclidean distance matrix (Anderson 2001). Spearman's rank correlation was used to test whether there was a correlation 
between the proportion of time spent foraging and trip duration. Hatching success (eggs hatched as a proportion of eggs laid), fledging success (chicks fledged as a proportion of eggs hatched) and breeding success (chicks fledged as a proportion of eggs laid) were compared between years using a Pearson's chi-squared test. All statistical analyses were conducted in the R statistical environment 4.0.0 (R Core Team 2020).

\section{Results}

\subsection{Environmental variables and habitat selection}

\subsubsection{Inter-annual variations of oceanographic conditions}

During the whole study period, SST varied strongly, ranging from 10.9 to $21.5{ }^{\circ} \mathrm{C}$, exhibiting an annual cycle with significant differences between the seasons (ANOVA, $\mathrm{F}_{641.1}=$ 69.925, $P<0.001$ ), and significant inter-annual variations (ANOVA, $\mathrm{F}_{197.63}=58.194, P<0.001$ ). Importantly, the average temperature in summer preceding the common diving petrel breeding season in $2018\left(18.5 \pm 0.9^{\circ} \mathrm{C}\right)$ and $2019\left(18.2 \pm 1.1^{\circ} \mathrm{C}\right)$ were significantly warmer than in 2017 $\left(17.1 \pm 1.0^{\circ} \mathrm{C}\right)$ and $2020\left(16.5 \pm 1.3{ }^{\circ} \mathrm{C}\right)$, and it was above the average summer temperature for the period 1981-2010 $\left(17.2 \pm 1.1{ }^{\circ} \mathrm{C}\right)$. During the summer period, SST in Bass Strait was above the optimal temperature range of coastal krill (the main common diving petrel prey; $>19{ }^{\circ} \mathrm{C}$ ) for 84 days in $2018\left(32 \mathrm{~d}>20^{\circ} \mathrm{C}\right)$, and 94 days in $2019\left(28 \mathrm{~d}>20^{\circ} \mathrm{C}\right)$, while it was only 37 days above $19^{\circ} \mathrm{C}$ in $2017\left(0 \mathrm{~d}>20^{\circ} \mathrm{C}\right)$ and 6 days in $2020\left(0 \mathrm{~d}>20^{\circ} \mathrm{C}\right)($ Fig. 1$)$. 

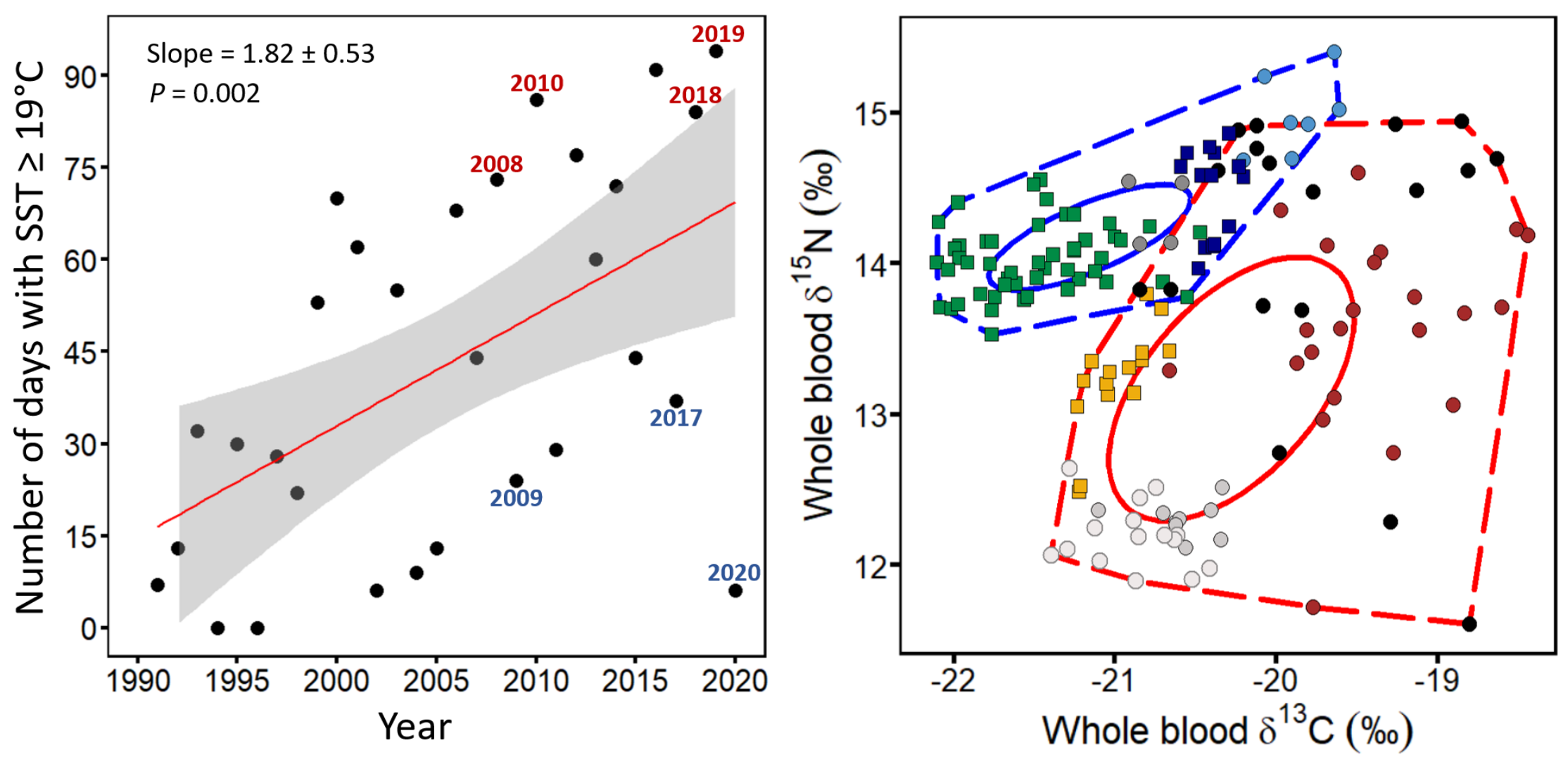

Figure 1: Left panel: Number of days per year with mean sea surface temperature above $19^{\circ} \mathrm{C}$ in Bass Strait, south-eastern Australia. Each dot corresponds to one year, and dots with a specified year correspond to the periods when blood samples were collected from common diving petrels on Kanowna Island (2008-2010 in Fromant et al. 2020c; 2017-2020 in the present study). The $19{ }^{\circ} \mathrm{C}$ threshold was selected based on the optimal temperature range of coastal krill $\left(12-18{ }^{\circ} \mathrm{C}\right.$; Sheard 1953$)$. A linear model was fitted to the data (red line; the analyses of residual and autocorrelation function plots showed no temporal autocorrelation pattern). Right panel: Whole blood $\delta^{13} \mathrm{C}$ and $\delta^{15} \mathrm{~N}$ values of common diving petrels $(P$. urinatrix) from Kanowna Island during cold (blue $40 \%$ ellipse and $100 \%$ total convex hull; 2009, 2017 and 2020) and warm years (red 40\% ellipse and 100\% total convex hull; 2008, 2010, 2018 and 2019). Incubation, dot symbols: red $=2018$; black $=2019$; light blue $=2020$. Chick-rearing, square symbols: green $=2017$; yellow $=2018$; dark blue $=2020$. Grey dots were adapted from Fromant et al. (2020c) (light grey, incubation 2008; dark gray, incubation 2009; open grey, incubation 2010). 


\subsubsection{Habitat selection modelling}

The final BRT model returned an AUC score of $0.96 \pm 0.01$ and identified salinity, wave direction and SST as the most important factors for predicting habitat selection (Table 1; Fig. S1). Salinity had a variable relative influence of $18.4 \%$, with fitted functions indicating that the probability of habitat selection decreased with increasing salinity. Both wave direction and SST had a lower variable relative influence (12.3\% and $11.4 \%$, respectively). For wave direction, fitted functions indicated that the probability of selection was relatively constant, although there were two slight peaks with wave direction from ESE $\left(110^{\circ}\right)$ and WNW (280$300^{\circ}$ ). For SST, fitted functions indicated that the probability of selection peaked at $12.5^{\circ} \mathrm{C}$, after which it remained relatively constant (Fig. S1).

The main variables influencing the habitat selection models varied between years and breeding stages (Table 1; Fig. S2). Similarly, the relative influence of each variable differed among the models. Salinity had a high relative influence for all the models except for chickrearing 2018 (7.1\%), while sea surface height and SST were significant only in the model for incubation 2019 (Fig. S2). 
Table 1: Model performance (AUC) and relative importance of environmental variables for the habitat selection models for common diving petrels (P. urinatrix) from Kanowna (Bass Strait, south-eastern Australia).

\begin{tabular}{|c|c|c|c|c|c|c|c|c|c|c|c|}
\hline & Model & $\mathbf{A U C}$ & Salinity & $\begin{array}{c}\text { Sea surface } \\
\text { temperate }\end{array}$ & $\begin{array}{c}\text { Sea surface } \\
\text { height }\end{array}$ & $\begin{array}{l}\text { Wave } \\
\text { period }\end{array}$ & $\begin{array}{c}\text { Wave } \\
\text { direction }\end{array}$ & $\begin{array}{c}\text { Current } \\
\text { speed }\end{array}$ & $\begin{array}{c}\text { Sea floor } \\
\text { slope }\end{array}$ & Bathymetry & $\begin{array}{c}\text { Mixed layer } \\
\text { thickness }\end{array}$ \\
\hline \multicolumn{2}{|c|}{$\begin{array}{c}\text { Combined years and } \\
\text { breeding stages }\end{array}$} & 0.96 & $18.4 \%$ & $11.4 \%$ & $11.2 \%$ & $10.8 \%$ & $12.3 \%$ & $11.2 \%$ & $10.3 \%$ & $8.0 \%$ & $6.5 \%$ \\
\hline 2017 & Chick-rearing & 0.96 & $41.5 \%$ & $9.4 \%$ & $8.2 \%$ & $8.5 \%$ & $8.4 \%$ & $5.6 \%$ & $7.2 \%$ & $8.8 \%$ & $2.5 \%$ \\
\hline \multirow{2}{*}{2018} & Incubation & 0.96 & $28.5 \%$ & $5.6 \%$ & $8.5 \%$ & $12.8 \%$ & $13.6 \%$ & $13.7 \%$ & $5.1 \%$ & $7.0 \%$ & $5.1 \%$ \\
\hline & Chick-rearing & 0.96 & $7.1 \%$ & $9.3 \%$ & $12.1 \%$ & $12.2 \%$ & $17.8 \%$ & $15.3 \%$ & $10.9 \%$ & $14.2 \%$ & $1.2 \%$ \\
\hline 2019 & Incubation & 0.97 & $14.1 \%$ & $20.3 \%$ & $16.5 \%$ & $12.6 \%$ & $10.4 \%$ & $6.4 \%$ & $5.4 \%$ & $5.1 \%$ & $9.1 \%$ \\
\hline \multirow{2}{*}{2020} & Incubation & 0.97 & $11.6 \%$ & $9.7 \%$ & $7.6 \%$ & $11.5 \%$ & $19.4 \%$ & $5.4 \%$ & $12.6 \%$ & $7.5 \%$ & $14.6 \%$ \\
\hline & Chick-rearing & 0.94 & $23.8 \%$ & $15.6 \%$ & $8.0 \%$ & $5.7 \%$ & $13.6 \%$ & $15 \%$ & $9.4 \%$ & $8.6 \%$ & $0.4 \%$ \\
\hline
\end{tabular}




\subsection{Breeding success}

Breeding success varied substantially between the four years of the study (Pearson's Chi-squared test, $\left.\chi^{2}=127.73, P<0.001\right)$, from $69 \%$ in $2017(\mathrm{n}=16)$ and $84 \%$ in $2020(\mathrm{n}=$ 50), to 6\% in $2018(\mathrm{n}=66)$ and $0 \%$ in $2019(\mathrm{n}=63)$ (Table 2). The very low breeding success in 2018 and 2019 was related to a delayed breeding season (a 30-50 days delay compared to the breeding seasons of 2017 and 2020; Kruskal-Wallis test: $\chi^{2}=112.75, P<0.001$ ), and related to low egg and chick survival (Table 2; Pearson's Chi-squared test, $\chi^{2}=46.291, P<$ 0.001 and $\chi^{2}=90.391, P<0.001$, respectively). The low hatching and breeding success in warmer years were associated with longer trips in 2018 (no data in 2019), larger foraging areas (in both 2018 and 2019) and lower whole blood $\delta^{15} \mathrm{~N}$ values (in both 2018 and 2019) (see Sections 3.3. and 3.4.). 
Table 2: Hatching, fledging and breeding success of common diving petrel ( $P$. urinatrix) from Kanowna Island (Bass Strait, south-eastern Australia). For each parameter, values not sharing the same superscript letter $(\mathrm{a}, \mathrm{b}$ or $\mathrm{c})$ are significantly different $(P<0.05$; Pearson's chi-squared test).

\begin{tabular}{cccc} 
Year & Hatching success & Fledging success & Breeding success \\
\hline 2017 & $81 \%(\mathrm{n}=16)^{\mathrm{a}}$ & $90 \%(\mathrm{n}=32)^{\mathrm{a}}$ & $69 \%(\mathrm{n}=16)^{\mathrm{a}}$ \\
2018 & $36 \%(\mathrm{n}=66)^{\mathrm{b}}$ & $17 \%(\mathrm{n}=24)^{\mathrm{b}}$ & $6 \%(\mathrm{n}=66)^{\mathrm{b}}$ \\
2019 & $41 \%(\mathrm{n}=63)^{\mathrm{b}}$ & $0 \%(\mathrm{n}=26)^{\mathrm{c}}$ & $0 \%(\mathrm{n}=63)^{\mathrm{c}}$ \\
2020 & $92 \%(\mathrm{n}=50)^{\mathrm{a}}$ & $91 \%(\mathrm{n}=46)^{\mathrm{a}}$ & $84 \%(\mathrm{n}=50)^{\mathrm{a}}$ \\
\hline
\end{tabular}




\subsection{Foraging parameters and at-sea distribution}

At-sea movement data were obtained from a total of 67 trips in incubation (36 individuals) and 122 trips during chick-rearing (65 individuals). Data for both the incubation and chick-rearing periods within the same season were collected in 2018 and 2020. Due to logistical constraints, no data were obtained during incubation in 2017. In 2019, all the study nests failed (young chicks found dead in the burrow) before any birds could be equipped during the chick-rearing period.

There were no significant differences between the sexes (48 females and 53 males) in trip parameters $(P>0.05$ in all cases $)$ and, therefore, data from both sexes were pooled in all subsequent statistical analyses.

\subsubsection{Foraging parameters and at-sea distribution according to the breeding stage:}

incubation ws chick rearing

Within the same breeding season (in 2018 and 2020), habitat distribution differed between the incubation and chick-rearing periods (Fig. 2; home ranges during incubation was $42 \%$ larger than during chick-rearing in 2018, and $10 \%$ in $2020 ; \mathrm{BA}_{\text {incubation/chick-rearing }}=0.26$ in 2018 and 0.48 in 2020). In 2018, the total distance travelled was significantly different between the incubation and chick-rearing stages (Table 3; Mann-Whitney $U$ test: $U=483, P=0.020$ ). However, no significant differences in the trip parameters were found between the two breeding stages in 2020 .

Individuals consistently departed from the colony earlier during incubation than during the chick-rearing period (Table 3; Mann-Whitney $U$ test: $U=6064, P<0.001$ ), but no clear pattern was observed for the timing of return (Mann-Whitney $U$ test: $U=4758, P=0.062$ ). However, the time between departure and sunrise, and the time between sunset and return, were positively correlated to the total distance travelled. The sampling period did not influence the 
distance travelled per trip nor the proportion of time foraging, with no relation found between the daylight duration (a proxy of available foraging time) and both the total distance travelled (Spearman's correlation test: $S=1024604, P=0.221$, $r h o=0.089$ ) and the proportion of time spent foraging (Spearman's correlation test: $S=1202794, P=0.239$, rho $=-0.086$ ). 

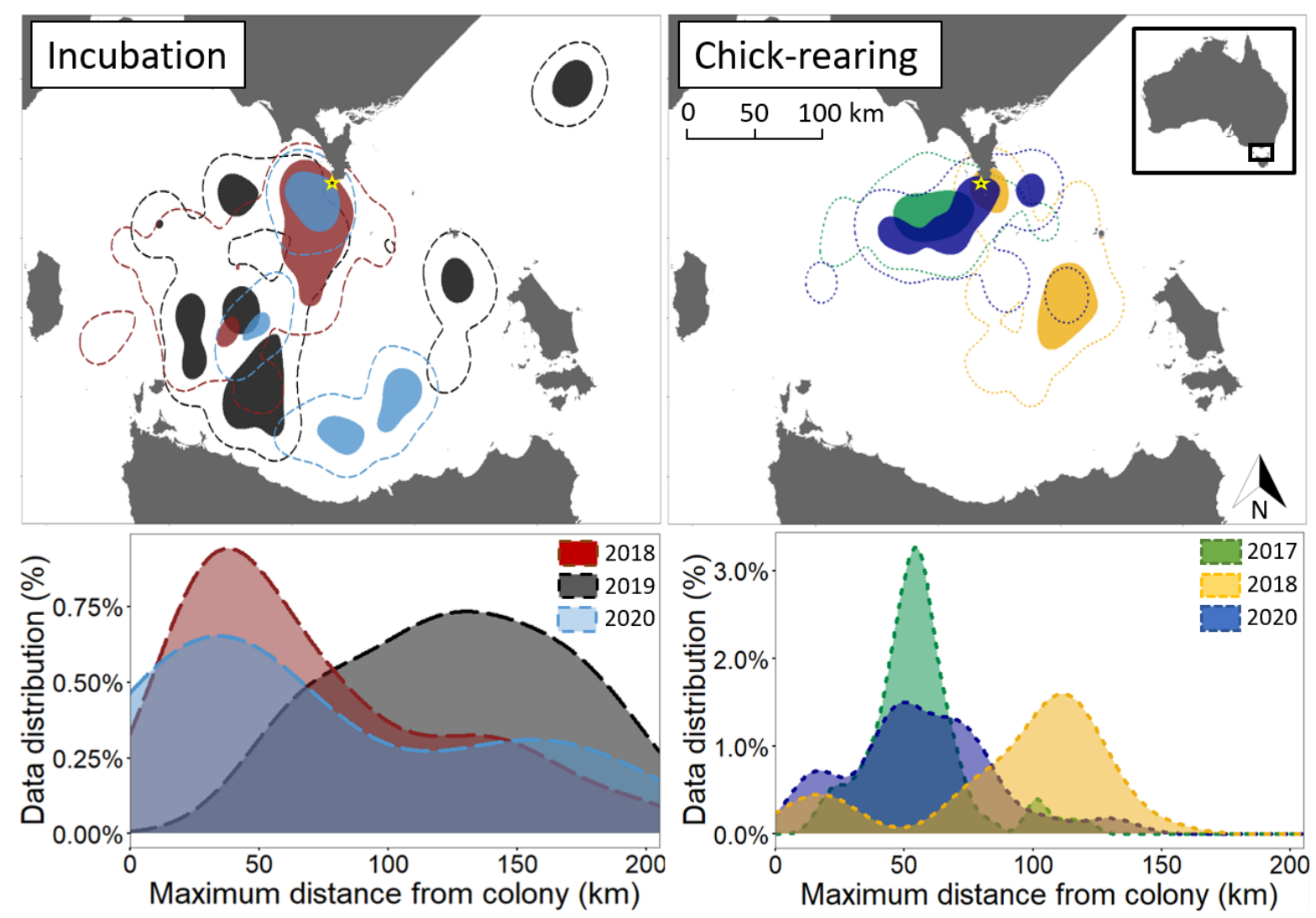

Figure 2: Upper panels: Foraging kernel density distribution estimated from GPS locations of common diving petrels ( $P$. urinatrix) in incubation (upper left) and chickrearing (upper right) from Kanowna Island, south-eastern Australia. Solid and open kernel areas show the 50 and $95 \%$ of the kernel utilization distribution, respectively (core area and home range, respectively).

Lower panels: Distribution density for maximum distance from colony to foraging locations per foraging trip of common diving petrel in incubation (lower left) and chickrearing (lower right) periods. 
Table 3: Summary of foraging trip metrics (mean \pm SE) for GPS-equipped common diving petrels (P. urinatrix) on Kanowna Island,

Bass Strait, south-eastern Australia. In 2017, no bird was tracked during incubation due to logistical constraints. In 2019, no bird was tracked during the chick-rearing period because of the early breeding failure of all the study individuals. For each parameter, values not sharing the same superscript letter (a, b or c) are significantly different $(P<0.05$; Mann-Whitney $U$ test for distance and time related parameters, and Rao's spacing test for bearings).

\begin{tabular}{|c|c|c|c|c|c|c|}
\hline & \multirow{2}{*}{$\begin{array}{c}2017 \\
\text { Chick-rearing } \\
\end{array}$} & \multicolumn{2}{|c|}{2018} & \multirow{2}{*}{$\begin{array}{c}2019 \\
\text { Incubation } \\
\end{array}$} & \multicolumn{2}{|c|}{2020} \\
\hline & & Incubation & Chick-rearing & & Incubation & Chick-rearing \\
\hline Number of trips (n) & $\mathrm{n}=70$ & $\mathrm{n}=47$ & $\mathrm{n}=30$ & $\mathrm{n}=13$ & $\mathrm{n}=7$ & $\mathrm{n}=22$ \\
\hline Number of individuals $(\mathrm{N})$ & $\mathrm{N}=38$ & $\mathrm{~N}=18$ & $\mathrm{~N}=12$ & $\mathrm{~N}=12$ & $\mathrm{~N}=6$ & $\mathrm{~N}=15$ \\
\hline Females $(\mathrm{F})$; Males $(\mathrm{M})$ & $F=16 ; M=22$ & $\mathrm{~F}=9 ; \mathrm{M}=9$ & $F=6 ; M=6$ & $F=6 ; M=6$ & $\mathrm{~F}=3 ; \mathrm{M}=3$ & $\mathrm{~F}=8 ; \mathrm{M}=7$ \\
\hline $\begin{array}{l}\text { Maximum distance from } \\
\text { colony }(\mathrm{km})\end{array}$ & $55.4 \pm 2.3^{\mathrm{a}}$ & $73.1 \pm 7.5^{\mathrm{ab}}$ & $92.0 \pm 7.0^{\mathrm{b}}$ & $127 \pm 12.1^{\mathrm{b}}$ & $75.5 \pm 27.0^{\mathrm{ab}}$ & $56.7 \pm 6.1^{\mathrm{a}}$ \\
\hline $\begin{array}{l}\text { Total distance travelled } \\
(\mathrm{km})\end{array}$ & $126 \pm 40.1^{\mathrm{a}}$ & $171 \pm 18.2^{\mathrm{a}}$ & $224 \pm 19.5^{\mathrm{b}}$ & $305 \pm 33.8^{\mathrm{b}}$ & $182 \pm 68.3^{\mathrm{ab}}$ & $134 \pm 14.5^{\mathrm{a}}$ \\
\hline Trip duration (h) & $\begin{array}{l}16.6 \pm 0.1^{\mathrm{a}} \\
(1 \mathrm{~d} \text { trip })\end{array}$ & $\begin{array}{l}23.9 \pm 2.1^{a b} \\
(1-3 d \text { trip })\end{array}$ & $\begin{array}{l}24.0 \pm 1.8^{\mathrm{bc}} \\
(1-2 \mathrm{~d} \text { trip })\end{array}$ & $\begin{array}{l}35.2 \pm 5.0^{c} \\
(1-3 \mathrm{~d} \text { trip })\end{array}$ & $\begin{array}{l}23.1 \pm 5.8^{\mathrm{ab}} \\
(1-2 \mathrm{~d} \text { trip })\end{array}$ & $\begin{array}{l}16.2 \pm 0.2^{\mathrm{a}} \\
(1 \mathrm{~d} \text { trip })\end{array}$ \\
\hline $\begin{array}{l}\text { Time between departure } \\
\text { and sunrise (min) }\end{array}$ & $87.9 \pm 5.8^{\mathrm{ab}}$ & $102 \pm 7.4^{\mathrm{c}}$ & $92.2 \pm 7.0^{\mathrm{bc}}$ & $137 \pm 14.6^{\mathrm{d}}$ & $123 \pm 17.0^{\mathrm{cd}}$ & $77.5 \pm 6.6^{\mathrm{a}}$ \\
\hline $\begin{array}{l}\text { Time between sunset and } \\
\text { return (min) }\end{array}$ & $101 \pm 3.9^{\mathrm{a}}$ & $120 \pm 8.3^{\mathrm{a}}$ & $173 \pm 14.0^{\mathrm{bc}}$ & $215 \pm 19.9^{c}$ & $119 \pm 33.8^{\mathrm{ab}}$ & $91.8 \pm 9.4^{\mathrm{a}}$ \\
\hline Bearing at departure $\left(^{\circ}\right)$ & $227 \pm 4.2^{\mathrm{a}}$ & $215 \pm 4.8^{\mathrm{a}}$ & $138 \pm 5.4^{\mathrm{a}}$ & $205 \pm 15.7^{\mathrm{a}}$ & $210 \pm 18.5^{\mathrm{a}}$ & $193 \pm 10.7^{\mathrm{a}}$ \\
\hline Bearing of distal point $\left({ }^{\circ}\right)$ & $233 \pm 3.8^{\mathrm{a}}$ & $218 \pm 4.9^{\mathrm{a}}$ & $135 \pm 4.3^{\mathrm{a}}$ & $216 \pm 15.2^{\mathrm{a}}$ & $209 \pm 14.0^{\mathrm{a}}$ & $194 \pm 12.3^{\mathrm{a}}$ \\
\hline
\end{tabular}




\subsubsection{Foraging parameters and at-sea distribution according to the years}

Home range differed inter-annually in size and location during both the incubation and chick-rearing periods (Fig. 2). The home range was the smallest in 2020 during the incubation and chick-rearing periods, and it was the largest in incubation 2019 and chick-rearing 2018. All parameters of foraging trips varied inter-annually, i.e. in terms of duration, total distance travelled, and maximum distance from the colony (Fig. 2; Table 3; Table S2; Kruskal-Wallis test, $P<0.001$ for all parameters).

In incubation, the proportion of foraging trips that were of $1 \mathrm{~d}$ duration varied from $74.5 \%$ in $2018,46.2 \%$ in 2019 and $66.7 \%$ in 2020 . During the chick-rearing period, the proportion ranged between $100.0 \%$ in 2017 and 2020, and $80.0 \%$ in 2018 . The longest trips (3 days) were observed during the incubation periods 2018 and 2019. Similarly, the proportion of time at sea spent in foraging/resting state varied inter-annually and between incubation and the chick-rearing periods (Kruskal-Wallis test: $\chi^{2}=69.74$, df $=3, P<0.001$ ); it was negatively correlated with the total distance travelled, for both $1 \mathrm{~d}$ trips (Fig. 3; Spearman's correlation test: $S=1254374, P<0.001$, rho $=-0.840$ ) and 2 d trips (Spearman's correlation test: $S=2890$, $P=0.002$, rho $=-0.632)$. 

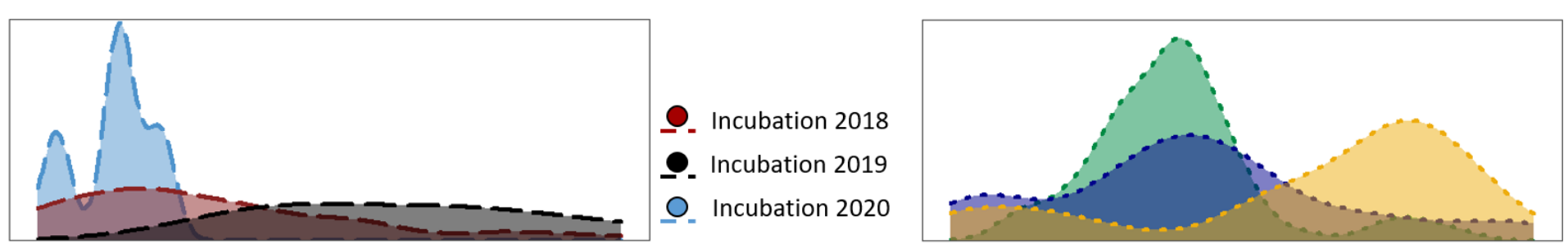

모. Chick-rearing 2017

ㅁ. . Chick-rearing 2018

모. Chick-rearing 2020
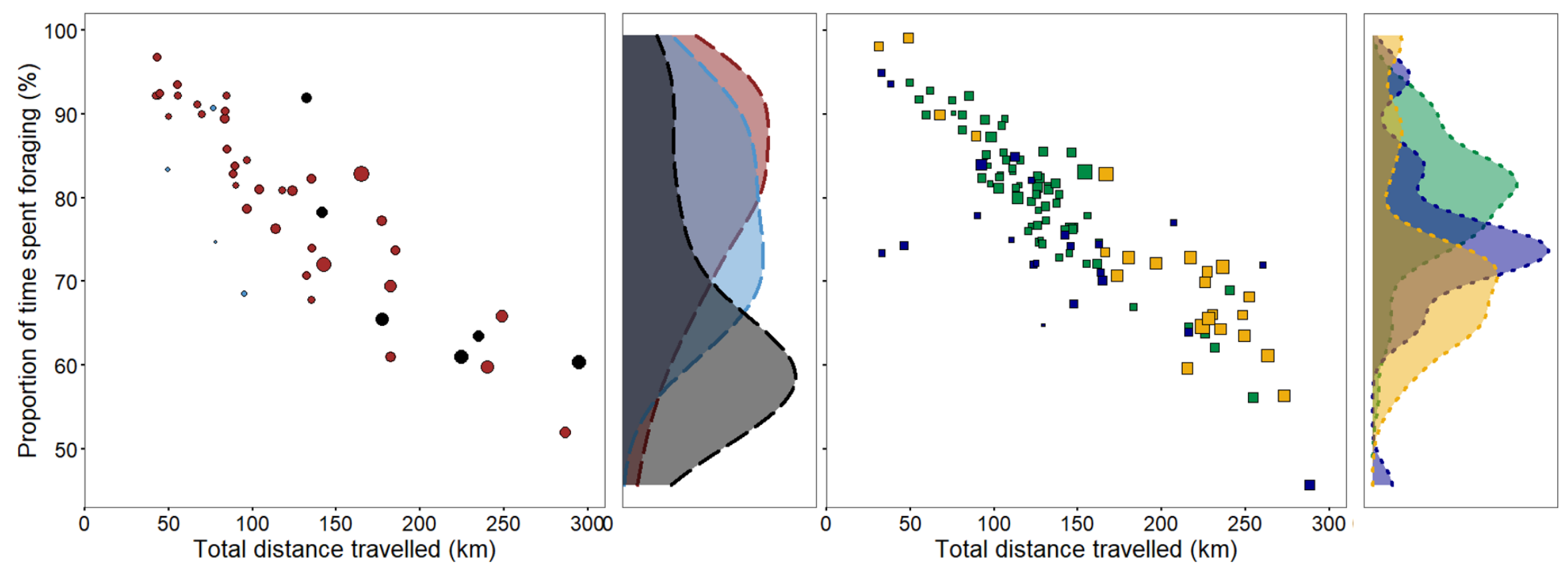

Figure 3: Correlation between the proportion of time spent foraging and total distance travelled per 1-day trip of common diving petrels $(P$. urinatrix) in incubation (left panels) and during the chick-rearing periods (right panels). The vertical and upper panels give the distribution density of the proportion of time spent foraging per trip and the total distance travelled per trip, respectively. The size of each point is proportional to the trip duration $(<24 \mathrm{~h})$. Trips longer than $24 \mathrm{~h}$ with overnight period at sea were not included in this figure. 


\subsection{Isotopic values for $\delta^{13} \mathrm{C}$ and $\delta^{15} \mathrm{~N}$}

Whole blood $\delta^{13} \mathrm{C}$ and $\delta^{15} \mathrm{~N}$ values varied substantially between years and breeding stages (Table 4; Fig. 4; PERMANOVA, $\mathrm{F}_{5}=50.81, \mathrm{R}^{2}=0.677, P=0.001 ;$ ANOVA, $P<0.001$ for both $\delta^{13} \mathrm{C}$ and $\left.\delta^{15} \mathrm{~N}\right)$. This variation was characterized by very limited isotopic niche overlap between stage/year (Table S3), all < 15\% except between incubation 2018 and incubation 2019 $\left(\mathrm{SEA}_{\mathrm{B}}\right.$ overlap $\left.=48 \%\right)$. During the same breeding season, both $\delta^{13} \mathrm{C}$ and $\delta^{15} \mathrm{~N}$ values were significantly higher in incubation than during the chick-rearing period. Values of $\delta^{13} \mathrm{C}$ were minimum in chick-rearing 2017 and maximum in incubation 2018 (ranging from -22.2 to $18.4 \%$ ), while $\delta^{15} \mathrm{~N}$ values were minimum in incubation 2019 and maximum in incubation 2020 (ranging from 11.6 to $15.4 \%$ ). The isotopic niche width was larger in incubation 2018 and 2019 (Fig. 4; Table S3; TA in incubation $2018=3.47$ and in incubation $2019=4.61$ ) than during the 2020 incubation period $(\mathrm{TA}=0.21)$. No such variations were observed during the chick-rearing period (Fig. 4; Table S3). 
Table 4: Summary of $\delta^{13} \mathrm{C}$ and $\delta^{15} \mathrm{~N}$ values in whole blood of common diving petrels (P. urinatrix) from Kanowna Island (Bass Strait, south-eastern Australia) during the incubation and chick-rearing periods. Values are means $\pm \mathrm{SD}$, with the number of individuals given in brackets. Values not sharing the same superscript letter (a, b, c, d or e) are significantly different $(P<0.05$; multiple comparisons with Tukey method for $\mathrm{p}$-value adjustment).

\begin{tabular}{ccccccc}
\hline Year & $\mathbf{2 0 1 7}$ & \multicolumn{2}{c}{$\mathbf{2 0 1 8}$} & $\mathbf{2 0 1 9}$ & \multicolumn{2}{c}{$\mathbf{2 0 2 0}$} \\
\cline { 3 - 4 } Breeding stage & Chick-rearing & Incubation & Chick-rearing & Incubation & Incubation & Chick-rearing \\
\hline Blood $\delta^{13} \mathrm{C}(\%)$ & $\begin{array}{c}-21.5 \pm 0.4^{\mathrm{a}} \\
(\mathrm{n}=51)\end{array}$ & $\begin{array}{c}-19.4 \pm 0.5^{\mathrm{b}} \\
(\mathrm{n}=23)\end{array}$ & $\begin{array}{c}-21.0 \pm 0.2^{\mathrm{c}} \\
(\mathrm{n}=16)\end{array}$ & $\begin{array}{c}-19.7 \pm 0.7^{\mathrm{b}} \\
(\mathrm{n}=20)\end{array}$ & $\begin{array}{c}-19.9 \pm 0.2^{\mathrm{b}} \\
(\mathrm{n}=9)\end{array}$ & $\begin{array}{c}-20.4 \pm 0.1^{\mathrm{d}} \\
(\mathrm{n}=15)\end{array}$ \\
Blood $\delta^{15} \mathrm{~N}(\%)$ & $\begin{array}{c}14.0 \pm 0.2^{\mathrm{a}} \\
(\mathrm{n}=51)\end{array}$ & $\begin{array}{c}13.6 \pm 0.6^{\mathrm{b}} \\
(\mathrm{n}=23)\end{array}$ & $\begin{array}{c}13.2 \pm 0.4^{\mathrm{c}} \\
(\mathrm{n}=16)\end{array}$ & $\begin{array}{c}14.0 \pm \\
1.0^{\mathrm{abe}} \\
(\mathrm{n}=20)\end{array}$ & $\begin{array}{c}15.0 \pm 0.2^{\mathrm{d}} \\
(\mathrm{n}=9)\end{array}$ & $\begin{array}{c}14.5 \pm 0.3^{\mathrm{e}} \\
(\mathrm{n}=15)\end{array}$ \\
\hline
\end{tabular}




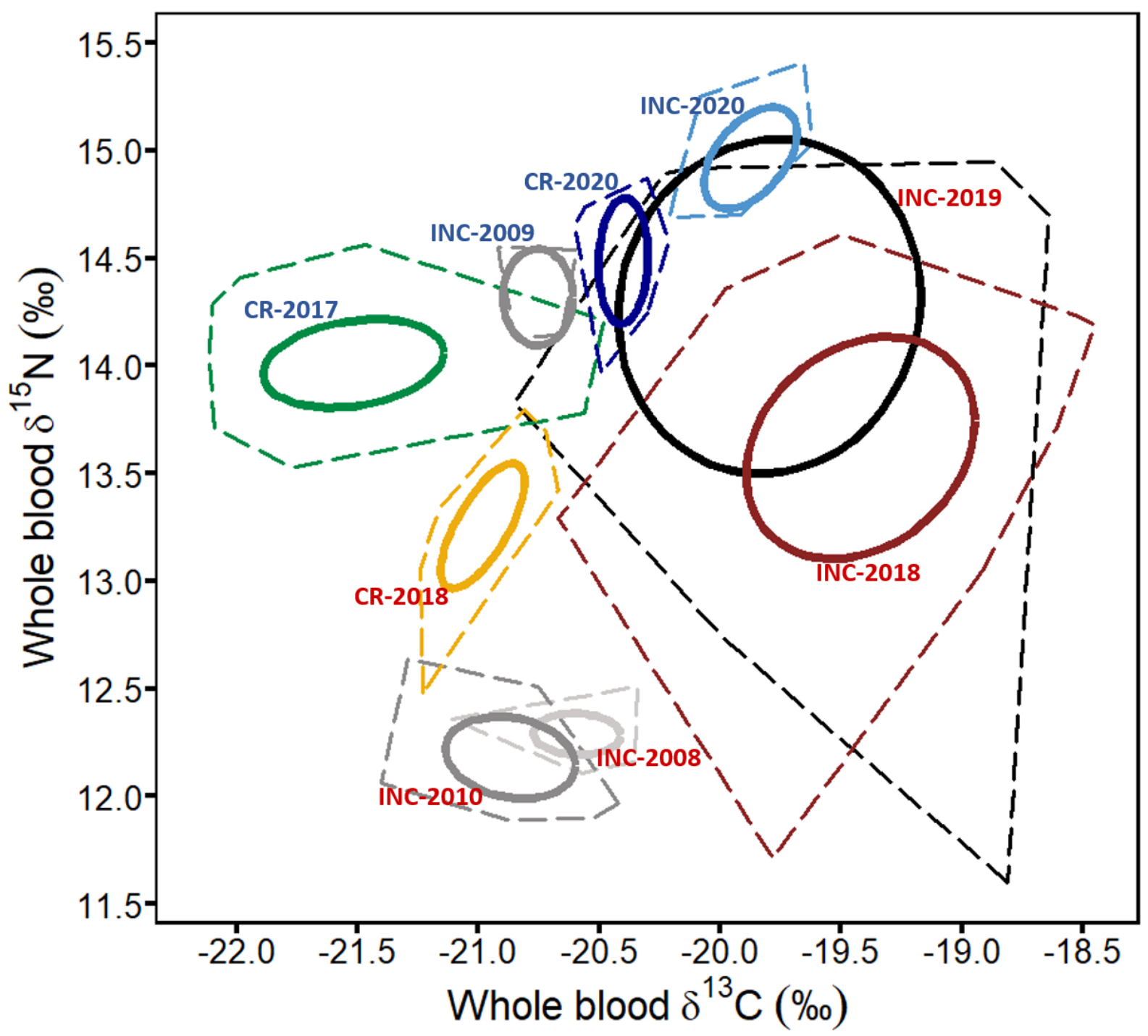

Figure 4: Whole blood $\delta^{13} \mathrm{C}$ and $\delta^{15} \mathrm{~N}$ values of common diving petrels ( $P$. urinatrix) from Kanowna Island in incubation (INC: red, 2018, $n=23$; black, 2019, $n=20$; light blue, 2020, $n=9$ ) and chick-rearing $(C R$ : green, 2017, $n=51$; yellow, 2018, $n=16$; dark blue, 2020, $\mathbf{n}=15$ ). Incubation 2008-2010 (grey) are whole blood $\delta^{13} \mathrm{C}$ and $\delta^{15} \mathrm{~N}$ values of common diving petrels in incubation from Kanowna Island obtained from Fromant et al., $2020(2008, n=10 ; 2009, n=4 ; 2010, n=15)$. Full lines correspond to the $40 \%$ ellipse and dashed lines $100 \%$ total convex hull. The blue and red writing represent cold and warm years, respectively (see Figure 1). 


\section{Discussion}

Using a combination of GPS tracking and stable isotope analyses, the present study documented for the first time substantial variations over four successive breeding cycles in the at-sea movements, foraging behaviour and trophic niche of a small planktonic forager, the common diving petrel. The salient features of the results can be summarized as following: i) these inter-annual variations coincided with drastic fluctuations in reproductive success and were associated with intense summer marine heatwave events; ii) during years of low breeding success, common diving petrels strongly increased their foraging effort and shifted their trophic niche, likely in response to important variations in prey availability; iii) the clear cascading effects that marine heatwaves have on the breeding and foraging ecology of this zooplankton feeder (Fig. 5) illustrate the rapid bottom-up effect induced by extreme environmental variations. 


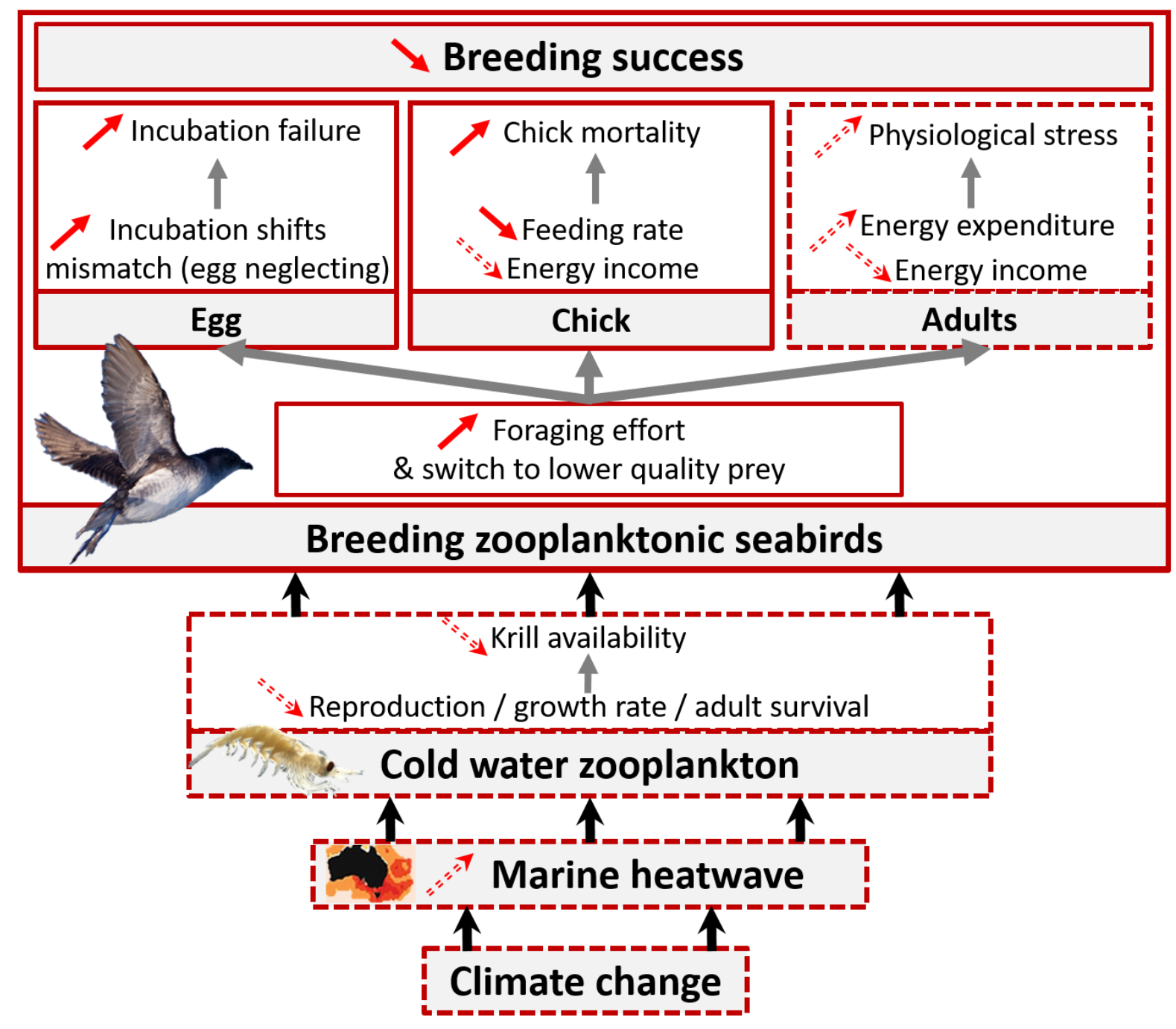

Figure 5: Cause-effect diagram illustrating the bottom-up effect of marine heatwaves on the breeding output of zooplankton-eating seabirds. For species breeding on the edge of their distribution range, the predicted intensification of marine heatwaves is likely to strengthen the detrimental effects on their breeding output. Full red blocks and arrows are results observed in the present study; Dotted red blocks and arrows are adapted from the literature (Young et al. 1993, Harding et al. 2007, Cohen et al. 2014, Oliver et al. 2017, Evans et al. 2020) (photo (C: A. Slotwinski and G. Jones) 


\subsection{Foraging behaviour, at-sea distribution and habitat use}

In all studied years, the foraging activity of the common diving petrels breeding on Kanowna Island was consistently restricted to the shallow continental shelf of Bass Strait. Although, diving petrel species seem to appear morphologically better suited for short foraging trips during breeding (Navarro et al. 2013), common diving petrels in Bass Strait exhibited relatively long foraging trips (average maximum distance from the colony $=71 \pm 3 \mathrm{~km}$ ) both during the incubation and chick-rearing periods. In all breeding stages and years, the diving petrels from Kanowna Island foraged farther away from the colony and conducted foraging trips 2-6 times longer than conspecifics in New Zealand (Zhang et al. 2018, Dunphy et al. 2020) and Peruvian diving petrels (Pelecanoides garnotii) in Peru (Zavalaga \& Alfaro-Shigueto 2018).

The overall foraging distribution of common diving petrels in the present study was in accordance with at-sea observation of the species in south-eastern Australian waters (Reid et al. 2002), and matches the habitat distribution of their main prey, i.e. coastal krill (O'Brien 1988, Schumann et al. 2008). Blood isotope values in 2017-2020 were within the same range as those previously measured in common diving petrels from the Bass Strait (Fromant et al. 2020c) and New Zealand (Dunphy et al. 2020). The average blood $\delta^{15} \mathrm{~N}$ value (14.0\%o) corresponds to one trophic level above the values of coastal krill $\left(\delta^{15} \mathrm{~N}=11.7 \%\right.$; Cherel et al. 2005b), thus confirming the importance of this prey item in the diet of Australian common diving petrels (Schumann et al. 2008, Fromant et al. 2020c). However, the wide isotopic niche and the large differences in at-sea distribution suggested seasonal and inter-annual prey variation in the diet of diving petrels in Bass Strait, potentially reflecting the complexity of this oceanographic system (Sandery \& Kämpf 2007).

Seabirds increase their foraging efficiency by identifying persistent oceanographic features where prey encountering is predictable (Weimerskirch 2007, Bost et al. 2009). In 
central Bass Strait, however, the oceanographic processes influencing the productivity are highly spatially and temporally variable (Sandery \& Kämpf 2007, Huang \& Wang 2019). The higher foraging effort and wide isotopic niche of common diving petrels in Bass Strait could, therefore, be due to the sparse distribution of their prey (O'Brien 1988), leading them to search farther and more widely than other diving petrel populations or similar species (Ryan \& Nel 1999, Zavalaga \& Alfaro-Shigueto 2018, Dunphy et al. 2020).

Salinity, wave direction and sea surface temperature appeared to be the most meaningful variables to describe the foraging distribution of the common diving petrel in Bass Strait. Higher preference to low salinity and low sea surface temperature is likely to reflect the optimal environmental conditions influencing their prey distribution (Sheard 1953, Evans et al. 2020). Such preferences are consistent with distribution models based on at-sea observation of common diving petrels in south-eastern Tasmania, with bird sightings being negatively correlated to SST and salinity (Evans et al. 2021).

However, the important inconsistencies in the habitat selection models between breeding stages and years may suggest a more complex association between potential prey and oceanographic features, and illustrate the oceanographic complexity of the region (Sandery \& Kämpf 2007). Additionally, the mismatch in resolution between tracking and environmental variables data may have failed to capture the scale at which the phenomenon occurs, impeding our interpretations. A finer resolution should enable in the future to fully understand what parameters influence the at-sea movements of common diving petrels.

\subsection{Inter-annual variation in breeding success, foraging behaviour and trophic niche}

The present study was characterised by two consecutive years of remarkably low breeding success (6\% in 2018 and 0\% in 2019; Marchant \& Higgins 1990, Chastel et al. 1995). 
At Kerguelen, the overall high breeding success of common diving petrels (46-86\% over seven years; Chastel et al. 1995) suggests that, during years of lower food availability, this species seems to be able to maintain its breeding output by increasing its foraging effort (Chastel et al. 1995). However, the same authors concluded that substantial shortage in food availability during the whole breeding season would likely induce an important decrease in breeding success.

In the present study, during years of very low breeding success, common diving petrels exhibited i) a higher distance travelled and lower nest attendance (longer trip duration), and ii) proportionately less time spent foraging per trip (longer foraging commutes). This higher foraging effort was associated with substantial variation in their isotopic niche (e.g. lower blood $\delta^{15} \mathrm{~N}$ values), suggesting a potential dietary shift from rich temperate zooplanktonic species to lower quality subtropical prey (Cohen et al. 2014, Evans et al. 2020). Such adjustments in relation to prey depletion is well documented among seabirds (Harding et al. 2007, Bost et al. 2015, Barbraud et al. 2018). However, the large decrease in breeding success of common diving petrel in Bass Strait, despite important modification in their foraging effort and trophic niche, underline the magnitude of the apparent disruption in prey availability.

As a key zooplankton species (Ritz \& Hosie 1982), variability in abundance of coastal krill has been observed to influence the foraging behaviour and demographic parameters of various marine predators (Mills et al. 2008, Manno et al. 2014). For example, in New Zealand, delayed breeding period, longer foraging trips and low breeding success of the zooplanktivorous red-billed gull (Larus novaehollandiae scopulinus) were linked to the absence of coastal krill in years of positive sea temperature anomaly (Mills et al. 2008). Similarly, in south-eastern Australia, a close relationship has been documented between coastal krill and the capture biomass of barracoota (Thyrsites atun) and jack mackerel (Trachurus 
declivis) by commercial fisheries, mitigated by the absence of coastal krill during years of high sea temperature anomaly (Young et al. 1993).

In the present study, summers preceding the very low breeding success of common diving petrel (2018 and 2019) were characterized by exceptionally long periods of SST above the optimal temperature range of coastal krill. The abnormal temperature conditions observed during these two successive summers is likely to have altered the availability of this key zooplanktonic species (Young et al. 1993, Mills et al. 2008). Previous marine heatwaves events in the region resulted in a shift of dominant species from large-bodied cold-water euphausiids to smaller size subtropical copepods (Evans et al. 2020). The depletion in the common diving petrel main prey in Bass Strait may have forced individuals to adapt their foraging ecology to prey of lower energetic value. In contrast, the mild SST in summer 2017 (fitting the 1981-2010 average) and the even colder summer 2020 were related to a much higher breeding success (69 and $84 \%$, respectively), indicating prey abundance. The large spectrum of SST observed in this study, within and outside the optimal temperature of coastal krill, therefore, illustrates a strong link between the oceanographic conditions, prey availability and predator breeding success.

The important inter-annual variations in blood isotopic values of common diving petrel (Fromant et al. 2020c, this study) are consistent with a substantial shift in their trophic niche during warmer years (Fig. 1). Alternatively, these variations could result from the spatiotemporal modification in the isotopic baselines in Bass Strait, leading ultimately to fluctuation in the isotopic values of common diving petrel prey (Jaeger \& Cherel 2011; Polito et al. 2019). However, the large isotopic niche width occupied by common diving petrels in 2018 and 2019 suggests a diversification in their diet, which may indicate a shortage in availability of their main prey following these marine heatwave events (Layman et al. 2007).

In South-Georgia, the reproductive performance of "krill-dependent" macaroni penguins (Eudyptes chrysolophus) decreased during years of poor Antarctic krill (Euphausia 
superba) availability (Waluda et al. 2012). These years were characterised by a broader diet, which was associated with increased energy and/or time costs. This is consistent with the greater foraging effort and wider isotopic niches observed for the common diving petrel in the present study during years of marine heatwaves. Likewise, in New Zealand, Hutton's shearwaters (Puffinus huttoni) adapted their behaviour by diving significantly deeper during the same marine heatwave events (Oliver et al. 2017, Perkins-Kirkpatrick et al. 2019, Bennet et al. 2020).

While the inter-annual variations in foraging ecology of the common diving petrel observed in the present study were concomitant with marine heatwaves in Bass Strait, their underlying mechanisms are poorly understood (Perkins-Kirkpatrick et al. 2019). Indeed, the thermal regime of Bass Strait is affected by several climatic and oceanographic features (Sandery \& Kämpf 2007), and further investigations are required to understand the link between environmental conditions, prey availability and the birds feeding and foraging behaviour.

\subsection{A potentially difficult future for small diving seabirds}

Reduction in prey availability during the breeding season in seabirds has been shown to result in increased foraging effort (e.g. Harding et al. 2007, Bost et al. 2015), lowered adult fitness and survival rate (Cohen et al. 2014, Piatt et al. 2020), and altered chick growth and breeding success (Quillfeldt et al. 2007, Waluda et al. 2012). Some seabird species can buffer disruptions in prey availability (Sommerfeld et al. 2015, Jakubas et al. 2020). However, as central place foragers, the high energetic demands during the breeding season sets a physiological limit that determines the effects of environmental variation on reproductive success and adult survival. The threshold that delineates seabird behavioural flexibility varies 
greatly among species and ecosystems, and is influenced by factors such as intra- and interspecific competition or geographic constraints.

Modification of zooplankton communities and abundance in marine systems in response to unprecedented periods of warming waters (McKinstry \& Campbell 2018, Evans et al. 2020) is likely to exacerbate the long-term bottom-up effect on higher-trophic levels (Möllmann et al. 2008, Sandford et al. 2019, Osborne et al. 2020). This may particularly intensify over the coming decades as such events are predicted to increase in magnitude and frequency (Oliver et al. 2019). In addition, considering the various anthropogenic perturbations in marine ecosystems (e.g. overfishing and pollution) and the rapidly changing oceanographic conditions, seabird flexibility may be increasingly challenged by the predicted intensification of extreme events such as marine heatwaves (Grémillet \& Boulinier 2009, Oliver et al. 2019).

Due to their high wing-loading (Warham 1977), the limited capacity of small diving seabird species to extend their foraging range during years of poor prey availability may impede their ability to adapt to more extreme environmental variations (Elliott et al. 2013). Additionally, unlike all other procellariiform species, the absence of stomach oil for diving petrels compels adults to deliver meals to their chick at high frequency (Roby 1989, Eizenberg et al. 2021). With more intense marine heatwaves predicted (Oliver et al. 2019), these constraints may affect diving petrel capacity to adapt to more frequent extreme events, and ultimately impact colony recruitment and drive local population/species declines (Bost et al. 2015, Péron et al. 2012). Indeed, the small population size of Peruvian (Cristofari et al. 2019) and Whenua Hou (Pelecanoides whenuahouensis; Fischer et al. 2018) diving petrels, or the geographic isolation of common diving petrels in Bass Strait (Fromant et al. 2020b) may exacerbate the long-term effects of climate change. 
In conclusion, the present study highlighted the sensitivity of a small macrozooplanktonic avian feeder, the common diving petrel, to environmental variability. While the time-series of the present study was relatively short, marine heatwave events were found to have a major impact at a regional scale on the food webs on which rely diving petrels. This suggests that common diving petrels in Bass Strait may have reached a critical threshold above which buffering the effects of such intense events on their reproductive output is not possible. In addition, the long-term effects of marine heatwaves on marine predators remain undescribed, and understanding their impact on adult survival is a key point for long-lived species. Focusing on species such as diving petrels, with high foraging constraints and feeding on low trophic-level prey, could help to disentangle the underlying mechanisms of long-term adaptation to climate change. Considering the wide geographic distribution (longitudinal and latitudinal gradients) of the common diving petrel throughout different environments of the Southern Hemisphere, this abundant seabird could act as a suitable environmental sentinel to monitor the effects of changing oceanographic conditions.

\section{Acknowledgements}

Fieldwork was conducted on Wamoon country, land of the Boon Wurrung, Bunurong and Gunaikurnai people. The authors thank the numerous volunteers for their help in the field, and G. Guillou from the Plateforme Analyses Isotopiques of the LIENSs laboratory for running stable isotope analysis. Thanks to the CPER (Contrat de Projet Etat-Région) and the FEDER (Fonds Européen de Développement Régional) for funding the IRMS of LIENSs laboratory. The IUF (Institut Universitaire de France) is acknowledged for its support to P. Bustamante as a Senior Member. We also thank two anonymous reviewers for their constructive comments on the manuscript. 


\section{Author Contributions}

AF conceived the study, collected field data, did the statistical analyses and drafted the manuscript; KD and JAB participated in the data analysis, helped drafting the manuscript and critically revised it; YHE, AL, JAB, BRG participated to the data collection, helped drafting the manuscript and critically revised it; $\mathrm{MBF}, \mathrm{PB}$ and $\mathrm{YC}$ were involved in stable isotopes analysis, helped drafting the manuscript and critically revised it; JPYA, CAB participated in the conception and coordination of the study, helped drafting the manuscript and critically revised it.

\section{Funding statement}

This study was supported logistically and financially by Sea World Research and Rescue Foundation Inc. and Birdlife Australia.

\section{Competing Interests}

The authors declare there are no competing interests

\section{References}

Amélineau F, Grémillet D, Bonnet D, Le Bot T, Fort J (2016) Where to forage in the absence of sea ice? Bathymetry as a key factor for an Arctic seabird. PloS ONE 11(7):e0157764. doi: 10.1371/journal.pone.0157764

Amélineau F, Grémillet D, Harding AM, Walkusz W, Choquet R, Fort J (2019) Arctic climate change and pollution impact little auk foraging and fitness across a decade. Sci Rep 9:1-15

Anderson MJ (2001) A new method for non-parametric multivariate analysis of variance. Austral Ecol 26:32-46 
Barbraud C, Bertrand A, Bouchón M, Chaigneau A, Delord K et al. (2018) Density dependence, prey accessibility and prey depletion by fisheries drive Peruvian seabird population dynamics. Ecography 41(7):1092-1102. doi: 10.1111/ecog.02485

Bearhop S, Waldron S, Votier SC, Furness RW (2002) Factors that influence assimilation rates and fractionation of nitrogen and carbon stable isotopes in avian blood and feathers. Physiol. Biochem Zool 75(5):451-458. doi: $\underline{10.1086 / 342800}$

Bennet DG, Horton TW, Goldstein SJ, Rowe L, Briskie JV (2020) Seasonal and annual variation in the diving behaviour of Hutton's shearwater (Puffinus huttoni). New Zeal J Zool 47:300-323. doi: 10.1080/03014223.2020.1767660

Bocher P, Cherel Y, Hobson KA (2000) Complete trophic segregation between South Georgian and common diving petrels during breeding at Iles Kerguelen. Mar Ecol Prog Ser 208:249-264. doi: $10.3354 / \operatorname{meps} 208249$

Bolker B, Skaug H, Magnusson A, Nielsen A (2012) Getting started with the glmmADMB package. http://glmmadmb.r-forge.r-project.org/glmmADMB.pdf

Bost CA, Jaeger A, Huin W, Koubbi P, Halsey LG, Hanuise N, Handrich Y (2008) Monitoring prey availability via data loggers deployed on seabirds: advances and present limitations. In: Tsukamoto K, Kawamura T, Takeuchi T, Beard TD, Kaiser MJ (eds) Fisheries for global welfare and environment. Terrapub, Tokyo, p 121-137

Bost CA, Cotté C, Bailleul F, Cherel Y, Charrassin JB, Guinet C, Ainley DG, Weimerskirch H (2009) The importance of oceanographic fronts to marine birds and mammals of the southern oceans. J Mar Syst 78:363-376. doi: 10.1016/j.jmarsys.2008.11.022

Bost CA, Cotté C, Terray P, Barbraud C, Bon C, Delord K, et al. (2015) Large-scale climatic anomalies affect marine predator foraging behaviour and demography. Nat Commun 6:8220. doi: 10.1038/ncomms9220

de L. Brooke M. (2004) The food consumption of the world's seabirds. Proc R Soc Lond B (Suppl) 271:S246-8.

Cai W, Shi G, Cowan T, Bi D, Ribbe J (2005) The response of the Southern Annular Mode, the East Australian Current, and the southern mid-latitude ocean circulation to global warming. Geophys. Res Lett 32:94-97. doi: 10.1029/2005GL024701

Cairns DK (1992) Bridging the gap between ornithology and fisheries science: use of seabird data in stock assessment models. The Condor 94:811-824. doi: $\underline{10.2307 / 1369279}$

Calenge C (2006) The package adehabitat for the R software: a tool for the analysis of space and habitat use by animals. Ecol Model 197:516-519. doi: $\underline{10.1016 / j . e c o l m o d e l .2006 .03 .017 ~}$ 
Chambers LE, Devney CA, Congdon BC, Dunlop N, Woehler E, Dann P (2011) Observed and predicted effects of climate on Australian seabirds. Emu 111:235-251. doi: $\underline{10.1071 / \mathrm{MU} 10033}$

Chastel O, Weimerskirch H, Jouventin P (1995) Body condition and seabird reproductive performance: a study of three petrel species. Ecology 76:2240-2246. doi: $\underline{10.2307 / 1941698}$

Cherel Y, Hobson KA, Hassani S (2005a) Isotopic discrimination between food and blood and feathers of captive penguins: implications for dietary studies in the wild. Physiol Biochem Zool 78(1):106-115. doi: 10.1086/425202

Cherel Y, Hobson KA, Weimerskirch H (2005b) Using stable isotopes to study resource acquisition and allocation in procellariform seabirds. Oecologia 145:533-540. doi: $\underline{10.1007 / \mathrm{s} 00442-005-0156-7}$

Cherel Y, Connan M, Jaeger A, Richard P (2014) Seabird year-round and historical feeding ecology: blood and feather $\delta^{13} \mathrm{C}$ and $\delta^{15} \mathrm{~N}$ values document foraging plasticity of small sympatric petrels. Mar Ecol Prog Ser 505:267-280. doi: 10.3354/meps10795

Chiaradia A, Forero MG, Hobson KA, Cullen JM (2010) Changes in diet and trophic position of a top predator ten years after a mass mortality of a key prey. ICES J Mar Sci 67:1710-1720. doi: 10.1093/icesjms/fsq067

Cohen LA, Pichegru L, Grémillet D, Coetzee J, Upfold L, Ryan PG (2014) Changes in prey availability impact the foraging behaviour and fitness of Cape gannets over decade. Mar Ecol Prog Ser 505:281-293. doi: 10.3354/meps10762

Cristofari R, Plaza P, Fernandez CE, Trucchi E, Gouin N, Le Bohec C, et al. (2019) Unexpected population fragmentation in an endangered seabird: the case of the Peruvian divingpetrel. Sci Rep 9:1-13. doi: 10.1038/s41598-019-38682-9

Dunphy BJ, Taylor GA, Landers TJ, Sagar RL, Chilvers BL, Ranjard L, et al. (2015) Comparative seabird diving physiology: first measures of haematological parameters and oxygen stores in three New Zealand Procellariiformes. Mar Ecol Prog Ser 523:187-198. doi: $10.3354 / \mathrm{meps} 11195$

Dunphy BJ, Vickers SI, Zhang J, Sagar RL, Landers TJ, Bury SJ, et al. (2020) Seabirds as environmental indicators: foraging behaviour and ecophysiology of common diving petrels (Pelecanoides urinatrix) reflect local-scale differences in prey availability. Mar Biol 167:1-12. doi: 10.1007/s00227-020-3672-4 
Elith J, Leathwick JR, Hastie T (2008) A working guide to boosted regression trees. J Anim Ecol 77:802-813. doi: 10.1111/j.1365-2656.2008.01390.x

Elliot KH, Le Vaillant M, Kato A, Speakman JR, Ropert-Coudert Y (2013) Accelerometry predicts daily energy expenditure in a bird with high activity levels. Biol Lett 9:20120919. doi: 10.1098/rsbl.2012.0919

Evans R, Lea MA, Hindell MA, Swadling KM (2020) Significant shifts in coastal zooplankton populations through the 2015/16 Tasman Sea marine heatwave. Estuar Coast Shelf Sci 235:106538. doi: $10.1016 /$ j.ecss.2019.106538

Evans R, Lea MA, Hindell MA (2021) Predicting the distribution of foraging seabirds during a period of heightened environmental variability. Ecol Appl 31(5):e02343. doi: 10.1002/EAP.2343

Fischer JH, Debski I, Miskelly CM, Bost CA, Fromant A, Tennyson AJD, et al. (2018) Analyses of phenotypic differentiations among South Georgian diving petrel (Pelecanoides georgicus) populations reveal an undescribed and highly endangered species from New Zealand. PLoS ONE 13:e0197766. doi: $\underline{10.1371 / \text { journal.pone.0197766 }}$

Franks PJS (1992) Phytoplankton blooms at fronts: patterns, scales, and physical forcing mechanisms. Rev Aquat Sci 6:121-137

Friedman JH (2001) Greedy function approximation: A gradient boosting machine. Annals Stat $1189-1232$

Fromant A, Miskelly CM, Arnould JPY, Bost CA (2020a) Artificial burrows as a tool for longterm studies of diving petrels. Polar Biol 19:1-8. doi: 10.1007/s00300-020-02645-y

Fromant A, Bost CA, Bustamante P, Carravieri A, Cherel Y, Delord K, et al. (2020b) Temporal and spatial differences in the post-breeding behaviour of a ubiquitous Southern Hemisphere seabird, the common diving petrel. R Soc Open Sci 7:200670. doi: $\underline{10.6084 / \mathrm{m} 9 . \text { figshare.c. } 5208533}$

Fromant A, Schumann N, Dann P, Cherel Y, Arnould JPY (2020c) Trophic niches of a seabird assemblage in Bass Strait, south-eastern Australia. Peerj 8:e8700. doi: $\underline{10.7717 / \text { peerj. } 8700}$

Fromant A, Eizenberg YH, Jessop R, Lec'hvien A, Geeson JJ, Arnould JPY (2020d) Colony relocation of Greater Crested Terns Thalasseus bergii in Bass Strait, south-eastern Australia. Australian Field Ornithol 37:166-171. doi: 10.20938/afo37166171

Gilmour ME, Castillo-Guerrero JA, Fleishman AB, Hernández-Vázquez S, Young HS, Shaffer SA (2018) Plasticity of foraging behaviors in response to diverse environmental 
conditions. Ecosphere 9:e02301. doi: 10.1002/ecs2.2301

Grémillet D, Boulinier T (2009) Spatial ecology and conservation of seabirds facing global climate change: a review. Mar Ecol Prog Ser 391:121-137. doi: 10.3354/meps08212

Grémillet D, Charmantier A (2010) Shifts in phenotypic plasticity constrain the value of seabirds as ecological indicators of marine ecosystems. Ecol Appl 20:1498-1503. doi: $\underline{10.1890 / 09-1586.1}$

Grémillet D, Welcker J, Karnovsky NJ, Walkusz W, Hall ME, Fort J, et al. (2012) Little auks buffer the impact of current Arctic climate change. Mar Ecol Prog Ser 454:197-206. doi: $\underline{10.3354 / \mathrm{meps} 09590}$

Guinet C, Cherel Y, Ridoux V, Jouventin P (1996) Consumption of marine resources by seabirds and seals in Crozet and Kerguelen waters: changes in relation to consumer biomass 1962-85. Antarctic Science 8(1):23-30

Harding AMA, Piatt JF, Schmutz JA, Shultz MT, van Pelt TI, Kettle AB, et al. (2007) Prey density and the behavioural flexibility of a marine predator: the common murre (Uria aalge). Ecology 88:2024-2033. doi: 10.1890/06-1695.1

Haury L, McGowan J, Wiebe P (1978) Patterns and processes in the time-space scales of plankton distributions. In: Steele JH (ed) Spatial pattern in plankton communities. NATO Conference Series (IV Marine Sciences), Vol 3. Springer, Boston, MA, p $277-327$

Hijmans RJ, Phillips S, Leathwick J, Elith J, Hijmans MRJ (2016) Package dismo. Circles 9:168

Hijmans RJ (2018) Raster: geographic data analysis and modeling. https://rspatial.org/raster Hindell MA, Reisinger RR, Ropert-Coudert Y, Hückstädt LA, Trathan PN, Bornemann H, et al. (2020) Tracking of marine predators to protect Southern Ocean ecosystems. Nature 580:87-92. doi: 10.1038/s41586-020-2126-y

Huang Z, Wang XH (2019) Mapping the spatial and temporal variability of the upwelling systems of the Australian south-eastern coast using 14-year of MODIS data. Remote Sensing Environ 227:90-109. doi: 10.1016/j.rse.2019.04.002

Hunt JG (1990) The pelagic distribution of marine birds in a heterogeneous environment. Polar Res 8:43-54. doi: 10.3402/polar.v8i1.6802

Jackson AL, Inger R, Parnell AC, Bearhop S (2011) Comparing isotopic niche widths among and within communities: SIBER-Stable Isotope Bayesian Ellipses in R. J Anim Ecol 80(3):595-602 
Jaeger A, Cherel Y (2011) Isotopic investigation of contemporary and historic changes in penguin trophic niches and carrying capacity of the Southern Indian Ocean. PLoS One 6(2):e16484. doi: 10.1371/journal.pone.0016484

Jakubas D, Wojczulanis-Jakubas K, Iliszko LM, Kidawa D, Boehnke R, Błachowiak-Samołyk K, et al. (2020) Flexibility of little auks foraging in various oceanographic features in a changing Arctic. Sci Rep 10:8283. doi: 10.1038/s41598-020-65210-x

Layman CA, Arrington DA, Montaña CG, Post DM (2007) Can stable isotope ratios provide for community-wide measures of trophic structure? Ecology 88:42-48

Lenth R (2020) emmeans: Estimated Marginal Means, aka Least-Squares Means. R package version 1.4.6.

Lund U, Agostinelli C, Arai H, Gagliardi A, Portugues EG, Giunchi D, et al. (2017) circular: Circular Statistics. https://cran.r-project.org/web/packages/ circular/index.html

Manno K, Loh G, van Heezik Y (2014) Buffering against food availability? The physical environment has little influence on breeding performance of fairy prions (Pachyptila turtur). Austral Ecol 29:548-559. doi: 10.1111/aec.12115

Marchant S, Higgins PJ (1990) Handbook of Australian, New Zealand and Antarctic Birds. Vol. 1. Oxford University Press, Melbourne

McKinstry CA, Campbell RW (2018) Seasonal variation of zooplankton abundance and community structure in Prince William Sound, Alaska, 2009-2016. Deep-Sea Res II 147:69-78. doi: $10.1016 /$ j.dsr2.2017.08.016

Mills JA, Yarrall JW, Bradford-Grieve JM, Uddstrom MJ, Renwick JA, Merilä J (2008) The impact of climate fluctuation on food availability and reproductive performance of the planktivorous red-billed gull Larus novaehollandiae scopulinus. J Anim Ecol 77:1129-1142. doi: 10.1111/j.1365-2656.2008.01383.x

Möllmann C, Müller-Karulis B, Kornilovs G, St John MA (2008) Effects of climate and overfishing on zooplankton dynamics and ecosystem structure: regime shifts, trophic cascade, and feedback loops in a simple ecosystem. ICES J Mar Sci 65:302-310. doi: $\underline{10.1093 / \text { icesjms/fsm197 }}$

Montevecchi WA, Hedd A, McFarlane Tranquilla L, Fifield DA, et al. (2012) Tracking seabirds to identify ecologically important and high risk marine areas in the western North Atlantic. Biol Conserv 156:62-71. doi: 10.1016/j.biocon.2011.12.001

Navarro J, Votier SC, Aguzzi J, Chiesa JJ, Forero MG, Phillips RA (2013) Ecological segregation in space, time and trophic niche of sympatric planktivorous petrels. PloS ONE 8:e62897. doi: 10.1371/journal.pone.0062897 
Navarro J, Votier SC, Phillips RA (2014) Diving capabilities of diving petrels. Polar Biol 37:897-901. doi: 10.1007/s00300-014-1483-0

O'Brien DP (1988) Surface schooling behaviour of the coastal krill Nyctiphanes australis (Crustacea: Euphausiacea) off Tasmania, Australia. Mar Ecol Prog Ser 42:219-233

Oliver ECJ, Benthuysen JA, Bindoff NL, Hobday AJ, Holbrook NJ, Mundy CN, et al. (2017) The unprecedented 2015/16 Tasman Sea marine heatwave. Nat Commun 8:1-12. doi: $\underline{10.1038 / \text { ncomms } 16101}$

Oliver ECJ, Burrows MT, Donat MG, Sen Gupta A, Alexander LV, Perkins-Kirkpatrick SE, et al. (2019) Projected marine heatwaves in the 21st century and the potential for ecological impact. Front Mar Sci 6:1-12. doi: 10.3389/fmars.2019.00734

Oliver ECJ, Benthuysen JA, Darmaraki S, Donat MG, Hobday AJ, Holbrook NJ et al. (2021) Marine heatwaves. Annu Rev Mar Sci 13:20.1-20.30. doi: 10.1146/annurev-marine$\underline{032720-095144}$

Osborne OE, O'Hara PD, Whelan S, Zandbergen P, Hatch SA, Elliot KH (2020) Breeding seabirds increase foraging area in response to an extreme marine heatwave. Mar Ecol Prog Ser 646:161-173. doi: 10.3354/meps13392

Perkins-Kirkpatrick SE, King AD, Cougnon EA, Holbrook NJ, Grose MR, Oliver ECJ, et al. (2019) The role of natural variability and anthropogenic climate change in the 2017/18 Tasman Sea marine heatwave. Bull Am Meteorol Soc 100:S105-110. doi: $\underline{10.1175 / B A M S-D-18-0116.1 ~}$

Péron C, Weimerskirch H, Bost CA (2012) Projected poleward shift of king penguins' (Aptenodytes patagonicus) foraging range at the Crozet Islands, southern Indian Ocean. Proc R Soc B 279:2515-23. doi: 10.1098/rspb.2011.2705

Piatt JF, Harding AMA, Schultz M, Speckman SG, van Pelt TI, Drew GS, et al. (2007) Seabirds as indicators of marine food supplies: Cairns revisited. Mar Ecol Prog Ser 352:221234. doi: $10.3354 / \mathrm{meps} 07078$

Piatt JF, Parrish JK, Renner HM, Schoen SK, Jones TT, Arimitsu ML, et al. (2020) Extreme mortality and reproductive failure of common murres resulting from the northeast Pacific marine heatwave of 2014-2016. PLoS ONE 15e0226087. doi: 10.1371/journal.pone.0226087

Polito MJ, Trivelpiece WZ, Reiss CS, Trivelpiece SG, Hinke JT, Patterson WP, Emslie SD (2019) Intraspecific variation in a dominant prey species can bias marine predator dietary estimates derived from stable isotope analysis. Limnol Oceanogr Methods 17(4):292-303. doi: 10.1002/lom3.10314 
Poloczanska E, Babcock R, Butler A, Hobday A, Hoegh-Guldberg O, Kunz T, et al. (2007) Climate change and Australian marine life. Oceanogr Mar Biol 45:407-478

Price CA, Hartmann K, Emery TJ, Woehler EJ, McMahon CR, Hindell MA (2020) Climate variability and breeding parameters of a transhemispheric migratory seabird over seven decades. Mar Ecol Prog Ser 643:191-205. doi: 10.3354/meps13328

Quillfeldt P, Strange IJ, Masello JF (2007) Sea surface temperatures and behavioural buffering capacity in thin-billed prions Pachyptila belcheri: breeding success, provisioning and chick begging. J Avian Biol 38:298-308. doi: 10.1111/j.2007.0908-8857.03846.x

Quillfeldt P, Masello JF (2013) Impacts of climate variation and potential effects of climate change on South American seabirds - a review. Mar Biol Res 9:337-357. doi: $\underline{10.1080 / 17451000.2012 .756982}$

R Core Team (2020) R: a Language and Environment for Statistical Computing R Foundation for Statistical Computing, Vienna, Austria

Raymond B, Wotherspoon S, Reisinger R (2016) Availability: estimating geographic space available to animals based on telemetry data. https://github.com/ryanreisinger/ availability

Reid K, Croxall JP, Edwards TM, Hill HJ, Prince PA (1997) Diet and feeding ecology of the diving petrels Pelecanoides georgicus and P. urinatrix at South Georgia. Polar Biol 17:17-24. doi: $\underline{10.1007 / \mathrm{s} 003000050100}$

Reid TA, Hindell MA, Eades DW, Newman M (2002) Seabird Atlas of South-eastern Australian Waters. Birds Australia Monograph 4. Birds Australia, Melbourne.

Reisinger RR, Raymond B, Hindell MA, Bester MN, Crawford RJ, Davies D, de Bruyn PN, Dilley BJ, Kirkman SP, Makhado AB, Ryan PG (2018) Habitat modelling of tracking data from multiple marine predators identifies important areas in the Southern Indian Ocean. Divers Distrib 24(4):535-550. doi: $10.1111 /$ ddi.12702

Ritz D, Hosie G (1982) Production of the euphausiid Nyctiphanes australis in Storm Bay, south-eastern Tasmania. Mar Biol 68:103-108

Roby DD (1989) Chick feeding in the diving petrels Pelecanoides georgicus and P. urinatrix exsul. Antarct Sci 1:337-342

Ross GJB, Burbidge AA, Brothers N, Canty P, Dann P, Fuller PJ, et al. (2001) The status of Australia's seabirds. In: Zann LP, Kailola P, eds. The state of the marine environment report for Australia technical annex: 1 the marine environment. Ocean Rescue 2000. Department of the Environment, Sport and Territories, Canberra 167-182 
Ryan PG, Nel DC (1999) Foraging behaviour of diving petrels Pelecanoides. Emu 99:72-74. doi: $10.1071 / \mathrm{MU} 99009 \mathrm{~B}$

Sandery PA, Kämpf J (2007) Transport timescales for identifying seasonal variation in Bass Strait, south-eastern Australia. Estuar Coast Shelf Sci 74:684-696. doi: $\underline{10.1016 / \text { j.ecss.2007.05.011 }}$

Sanford E, Sones JL, García-Reyes M, Goddard JH, Largier JL (2019) Widespread shifts in the coastal biota of northern California during the 2014-2016 marine heatwaves. Sci Rep 9:4216. doi: 10.1038/s41598-019-40784-3

Schumann N, Arnould JPY, Dann P (2008) Diet of common diving-petrels (Pelecanoides urinatrix urinatrix) in southeastern Australia during chick rearing. Waterbirds 31:620-624. doi: 10.1675/1524-4695-31.4.620

Schumann N, Dann P, Arnould JPY (2014) The significance of northern-central Bass Strait in south-eastern Australia as habitat for burrowing seabirds. Emu 114:234-240. doi: $\underline{10.1071 / M U 13048}$

Sheard K (1953) Taxonomy, distribution, and development of Euphausiacea (Crustacea). Report of British Australian and New Zealand Antarctic Research Expedition Series B (Zoology and Botany) 8:1-72

Sommerfeld J, Kato A, Ropert-Coudert Y, Garthe S, Wilcox C, Hindell MA (2015) Flexible foraging behaviour in a marine predator, the masked booby (Sula dactylatra), according to foraging locations and environmental conditions. J Exp Mar Biol Ecol 463:79-86. doi: 10.1016/j.jembe.2014.11.005

Spear LB, Ainley DG (1997) Flight behaviour of seabirds in relation to wind direction and wing morphology. Ibis 139:221-233. doi: 10.1111/j.1474-919X.1997.tb04620.x

Waluda CM, Hill SL, Peat HJ, Trathan PN (2012) Diet variability and reproductive performance of macaroni penguins Eudyptes chrysolophus at Bird Island, South Georgia. Mar Ecol Prog Ser 466:261-274. doi: 10.3354/meps09930

Warham J (1977) Wing loading, wing shapes, and flight capabilities of Procellariiformes. New Zeal J Zool 4:73-83

Weimerskirch H, Salamolard M, Sarrazin F, Jouventin P (1993) Foraging strategy of wandering albatrosses through the breeding season: a study using satellite telemetry. Auk 110:325-342

Weimerskirch H, Chastel O, Ackermann L, Chaurand T, Cuenot-Chaillet F, Hindermeyer X, et al. (1994) Alternate long and short foraging trips in pelagic seabird parents. Anim Behav 47:472-476 
Weimerskirch H (2007) Are seabirds foraging for unpredictable resources? Deep-Sea ResII 54:211-223. doi: 10.1016/j.dsr2.2006.11.013

Worton BJ (1989) Kernel methods for estimating the utilization distribution in home-range studies. Ecology 70:164-168

Young J, Jordan A, Bobbi C, Johannes R, Haskard K, Pullen G (1993) Seasonal and interannual variability in krill (Nyctiphanes australis) stocks and their relationship to the fishery for jack mackerel (Trachurus declivis) off eastern Tasmania, Australia. Mar Biol 116:9-18

Zavalaga CB, Alfaro-Shigueto J (2018) Foraging movements of Peruvian diving-petrels in Isla La Vieja, Peru. Pacific Seabird Group Conservation Small-grant Program 2011

Zhang J, Rayner M, Vickers S, Landers T, Sagar R, Stewart J, et al. (2019) GPS telemetry for small seabirds: using hidden Markov models to infer foraging behaviour of common diving petrels (Pelecanoides urinatrix urinatrix). Emu 119:126-137. doi: $\underline{10.1080 / 01584197.2018 .1558997}$

Zuur AF, Ieno EN, Elphick CS (2010) A protocol for data exploration to avoid common statistical problems. Ecol Evol 1:3-14. doi: 10.1111/j.2041-210X.2009.00001.X 


\title{
Supplementary materials
}

\section{Impact of extreme environmental conditions: foraging behaviour and trophic ecology responses of a diving seabird, the common diving petrel.}

\author{
Supplementary text: Estimating the potential effects of short-term deployments of \\ miniaturised devices on adult common diving petrels.
}

In October/November 2017, adult birds were equipped during the chick-rearing period with lightweight GPS ( $\mathrm{n}=38$; nanoFix-GEO, Pathtrack Ltd, Otley, United-Kingdom) attached to two tail feathers using waterproof tape. The total mass of the equipment (GPS) corresponded to $2.3 \pm 0.2 \%$ of the birds' body mass $(1.8-2.7 \%, \mathrm{n}=38)$. The devices were deployed for 1 to 4 consecutive days $(2.2 \pm 0.8$ days $)$, and all the GPS were recovered. Individuals were weighed ( $\pm 2 \mathrm{~g}$; Pesola) before and after the deployment and retrieval of the device, respectively.

All the individuals remained in their burrow after handling until departure time the next morning. Birds equipped with a GPS departed on average $1.47 \pm 0.05$ hours before sunrise and return $1.67 \pm 0.02$ hours after sunset. This is in accordance with field observation and passive acoustic studies showing that common diving petrels leave the colony on average 1-2 hours before sunrise and return to the colony 1-2 hours after sunset (Thoresen 1969; Ranjard et al. 2017; Fromant et al. unpublished data).

All untracked birds and individuals equipped with a GPS did daily trips. There was no significant variation in body mass of instrumented individuals between the deployment and the retrieval $(130 \pm 2 \mathrm{~g}$ and $134 \pm 2 \mathrm{~g}$, respectively; $\mathrm{n}=38$; Mann-Whitney $U$ test: $U=1085, P=$ 
0.151). Similarly, there was no difference between the body mass of birds when retrieved and control individuals (134 $\pm 2 \mathrm{~g}$ and $133 \pm 1 \mathrm{~g}$, respectively; $\mathrm{n}=38$ and 89, respectively; MannWhitney $U$ test: $U=2191.5, P=0.737)$. These results are consistent with Navarro et al. (2014) that found no effect of TDRs deployment on trip duration and body mass of common and South Georgian diving petrels in South Georgia.

Growth curve analysis method (Mirman 2014) was used to investigate the potential effect of GPS deployment of parent birds on chick growth. Chicks were monitored approximately every 3-5 d, depending on weather conditions. Individuals were weighed in a cloth bag with a Pesola spring scale $( \pm 2 \mathrm{~g})$, bill and tarsus measurements were taken with Vernier callipers $( \pm 0.1 \mathrm{~mm})$ and wing length was measured with a shoulder stopped ruler $( \pm$ $1.0 \mathrm{~mm})$. The growths of body mass, wing length, tarsus length and bill length were modelled with a third-order orthogonal polynomial and fixed effects on all age terms of conditions $($ Control $=$ no deployment versus Instrumented $=$ adults equipped with a GPS $)$. The model also included chick-ID random effects and chick-ID by condition random effects. For all studied parameters (body mass, wing length, tarsus length and bill length), there was no significant effect of device deployment on the intercept term nor the curvature (Table S1), which indicates similar growth rates between the two groups.

Similarly, fledging success and fledging body mass of chicks did not differ between control and experimental groups (91\% and 95\% fledging success; $128 \pm 3 \mathrm{~g}$ and $126 \pm 2 \mathrm{~g}$ for control and experimental groups, respectively; paired $t$-test: $t_{11.755}=0.622, P=0.546$ ). 
Table S1: Parameter estimates for the analysis of the effect of equipment on chick growth curves.

\begin{tabular}{cccccc} 
& & Estimate & Std.Error & $\mathbf{t}$ & $\mathbf{p}$ \\
\hline \multirow{2}{*}{ Body } & Intercept & -1.40 & 2.89 & -0.46 & 0.628 \\
mass & Linear & 2.17 & 6.26 & -0.34 & 0.729 \\
& Quadratic & -0.08 & 3.92 & -0.02 & 0.983 \\
\hline \multirow{2}{*}{ Wing } & Intercept & -0.49 & 1.10 & -0.44 & 0.660 \\
length & Linear & -1.39 & 2.00 & -0.69 & 0.490 \\
& Quadratic & -0.23 & 1.45 & -.15 & 0.870 \\
\hline \multirow{2}{*}{ Tarsus } & Intercept & 0.07 & 0.30 & 0.24 & 0.804 \\
length & Linear & 0.28 & 0.43 & 0.66 & 0.506 \\
& Quadratic & -0.27 & 0.30 & -0.90 & 0.366 \\
\hline \multirow{2}{*}{ Bill length } & Intercept & 0.50 & 0.30 & 1.65 & 0.097 \\
& Linear & -1.11 & 1.19 & -0.93 & 0.350 \\
& Quadratic & 0.82 & 0.83 & 0.99 & 0.321 \\
\hline
\end{tabular}

\section{References:}

Mirman D (2014) Growth Curve Analysis and Visualization Using R. Chapman and Hall / CRC

Navarro J, Votier SC, Phillips RA (2014) Diving capabilities of diving petrels. Polar Biol 37:897-901

Ranjard L, Reed BS, Landers TJ, Rayner MJ, Friesen MR, Sagar RL, Dunphy BJ (2017) MatlabHTK: a simple interface for bioacoustics analyses using hidden Markov models. Methods Ecol Evol 8:615-621

Thoresen AC (1969) Observations on the breeding behaviour of the diving petrel Pelecanoides u. urinatrix (Gmelin). Notornis 16:241-260 
Table S2: Results of the GLMM models explaining trip parameters for common diving petrels from Kanowna Island in incubation $(2018, N=18 ; 2019, N=12 ; 2020, N=6)$ and during the chick-rearing period $(2017, N=38 ; 2018, N=12 ; 2020, N=15)$.

Explanatory variables, Akaike Information Criterion (AIC), Delta AIC (difference in AIC with the best model) and Log-likelihood are given for each model. Models are ranked according to their respective AIC value.

\begin{tabular}{|c|c|c|c|}
\hline Model & AIC & Delta AIC & Log-likelihood \\
\hline Total trip duration $\sim$ YEAR $*$ BREEDING STAGE & 1261.7 & 0 & -622.9 \\
\hline Total trip duration $\sim$ YEAR & 1264.0 & 5.2 & -626.0 \\
\hline Total trip duration $\sim$ BREEDING STAGE & 1295.0 & 36.1 & -643.5 \\
\hline Total trip duration $\sim \mathrm{SEX}$ & 1310.2 & 51.4 & -651.1 \\
\hline Total trip duration $\sim 1$ & 1312.0 & 53.1 & -652.9 \\
\hline Total distance per trip $\sim$ YEAR $*$ BREEDING STAGE & 1991.0 & 0 & -987.5 \\
\hline Total distance per trip $\sim$ YEAR & 2010.4 & 22.2 & -999.2 \\
\hline Total distance per trip BREEDING STAGE & 2057.7 & 69.5 & -1024.8 \\
\hline Total distance per trip $\sim$ SEX & 2063.7 & 75.3 & -1027.8 \\
\hline Total distance per trip $\sim 1$ & 2069.6 & 81.3 & -1031.8 \\
\hline Maximum distance per trip YEAR * BREEDING STAGE & 1677.7 & 0 & -830.8 \\
\hline Maximum distance per trip YEAR & 1691.3 & 16.3 & -839.7 \\
\hline Maximum distance per trip $~$ BREEDING STAGE & 1732.9 & 57.9 & -862.5 \\
\hline Maximum distance per trip $\sim$ SEX & 1739.7 & 64.7 & -865.9 \\
\hline Maximum distance per trip $\sim 1$ & 1744.1 & 68.9 & -869.0 \\
\hline Start direction $\sim$ YEAR $*$ BREEDING STAGE & 1682.7 & 0 & -833.3 \\
\hline Start direction $\sim$ YEAR & 1738.6 & 60.2 & -863.3 \\
\hline Start direction $\sim$ BREEDING STAGE & 1768.6 & 90.1 & -880.3 \\
\hline Start direction $\sim$ SEX & 1769.9 & 91.5 & -880.9 \\
\hline Start direction $\sim 1$ & 1774.2 & 95.8 & -884.1 \\
\hline Maximum range direction $\sim$ YEAR $*$ BREEDING STAGE & 1665.3 & 0 & -824.7 \\
\hline Maximum range direction $\sim$ YEAR & 1722.4 & 66.6 & -855.2 \\
\hline Maximum range direction $\sim$ BREEDING STAGE & 1756.4 & 100.9 & -874.2 \\
\hline Maximum range direction $\sim \mathrm{SEX}$ & 1758.4 & 102.5 & -875.2 \\
\hline Maximum range direction $\sim 1$ & 1762.7 & 106.8 & -878.3 \\
\hline
\end{tabular}


Table S3: Total area of the convex hull (TA), Bayesian standard ellipses areas (SEAB) and SEAв overlap of isotopic values in whole blood of common diving petrels (P. urinatrix) from Kanowna Island, south-eastern Australia. INC $=$ incubation; $\mathrm{CR}=\mathrm{Chick}$-rearing. CR 2017 INC 2018

CR 2018 INC 2019 INC 2020

CR 2020

\begin{tabular}{ccccccc}
\hline TA & 1.23 & 3.47 & 0.34 & 4.61 & 0.28 & 0.21 \\
\hline SEAB & 0.30 & 1.08 & 0.16 & 2.22 & 0.19 & 0.11 \\
\hline Overlap - CR 2017 & - & 0.00 & 0.06 & 0.05 & 0.00 & 0.03 \\
Overlap - INC 2018 & - & - & 0.02 & 0.48 & 0.05 & 0.03 \\
Overlap - CR 2018 & - & - & - & 0.05 & 0.00 & 0.02 \\
Overlap - INC 2019 & - & - & - & - & 0.09 & 0.05 \\
Overlap - INC 2020 & - & - & - & - & - & 0.15 \\
Overlap - CR 2020 & - & - & - & - & - & - \\
\hline
\end{tabular}


Figure S1: Fitted functions for each environmental covariate used to assess the probability of habitat selection of common diving petrels (P. urinatrix) from Kanowna Island, south-eastern Australia.

Environmental covariates include (in increasing order of importance): salinity (SAL), wave direction (WVD), sea surface temperate (SST), sea surface height (SSH), current speed (CUR), wave period (WVP), sea floor slope (SLO), bathymetry (DEP) and mixed layer thickness (MLT).
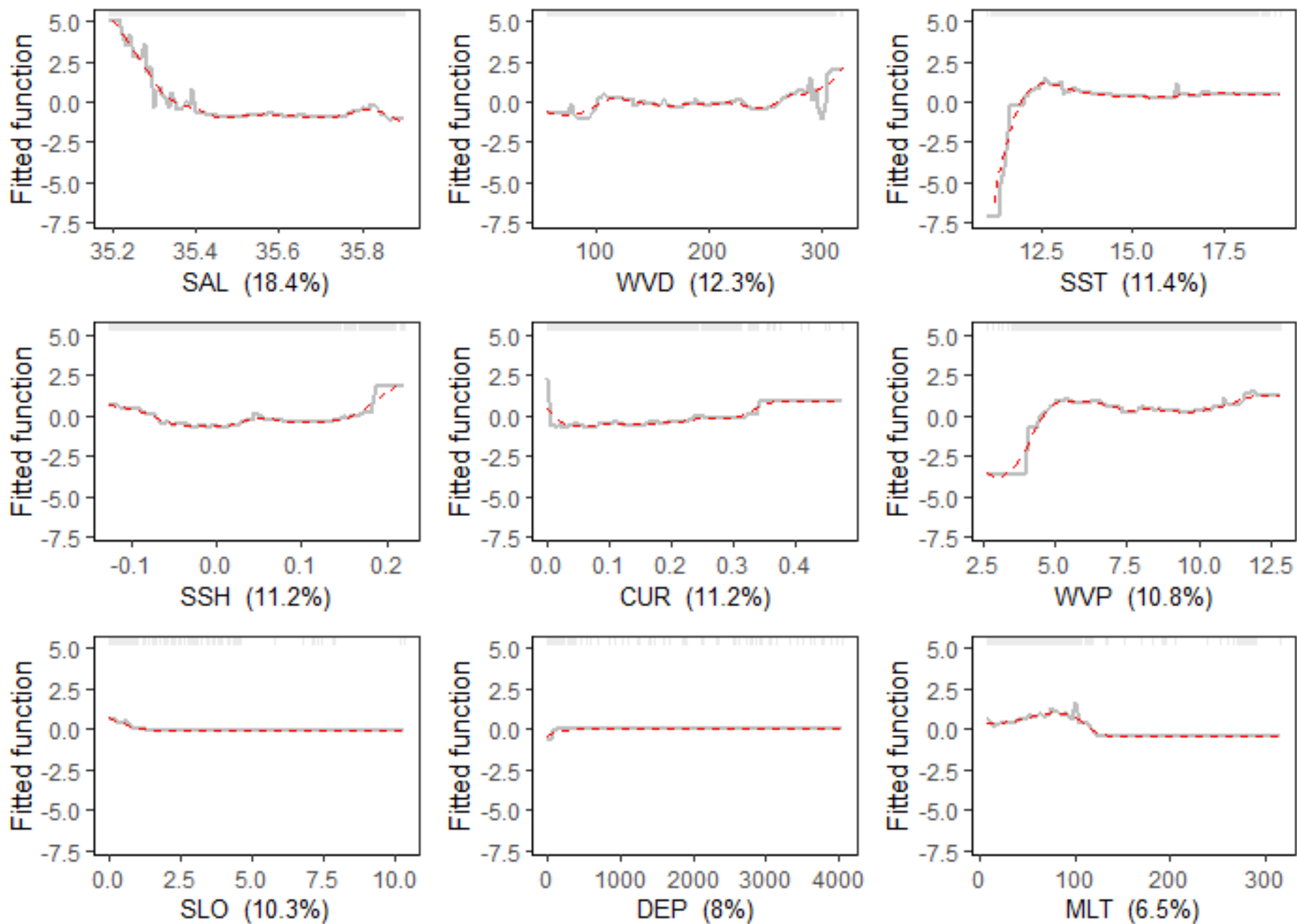
Figure S2: Fitted functions for each year and breeding stage of habitat selection of common diving petrels $(P$. urinatrix) from Kanowna Island, south-eastern Australia.

Environmental covariates: salinity (SAL), sea surface height (SSH), sea surface temperate (SST), wave period (WVP), current speed (CUR), wave direction (WVD), sea floor slope (SLO), bathymetry (DEP) and mixed layer thickness (MLT).

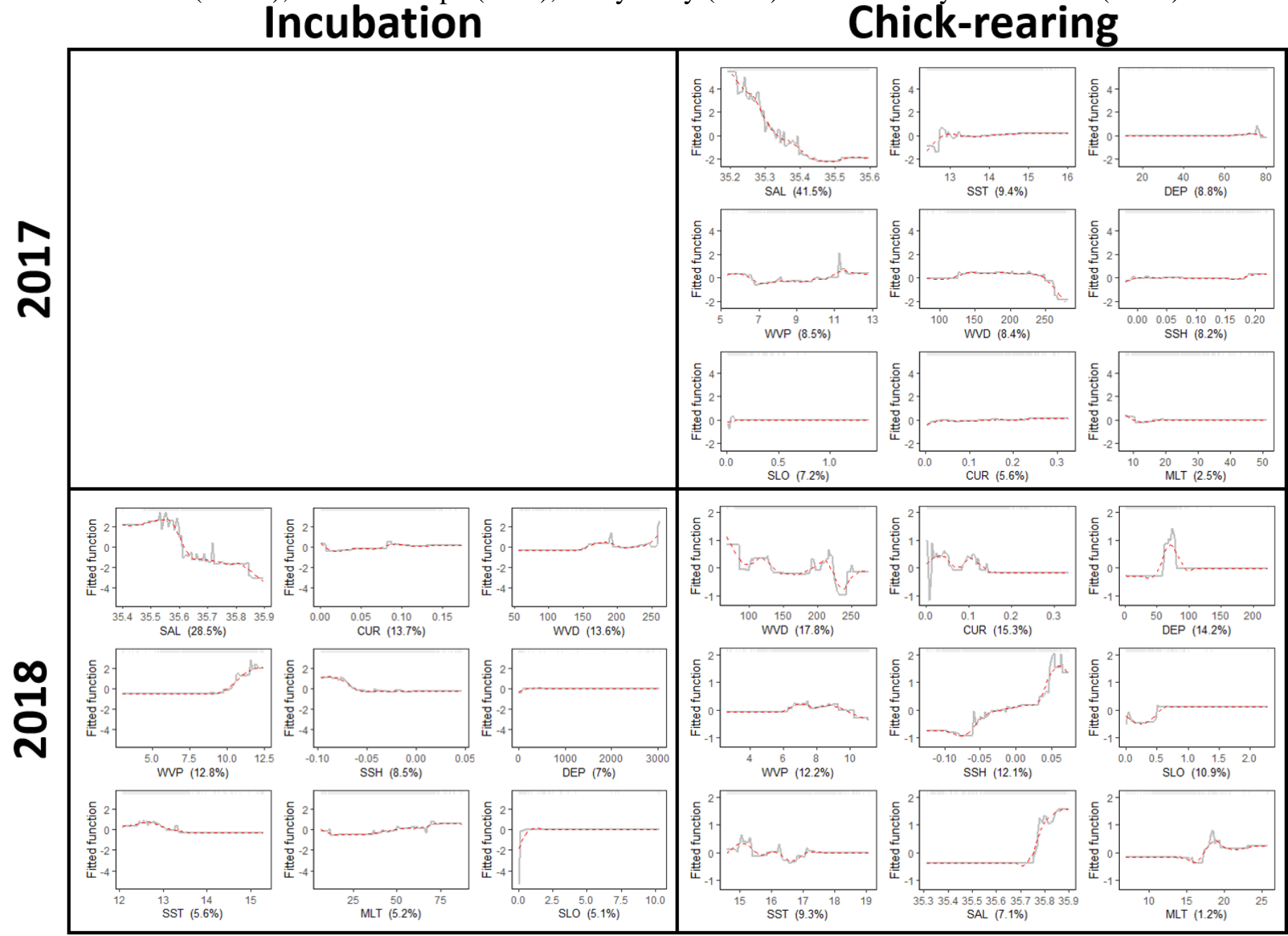


Figure S2:

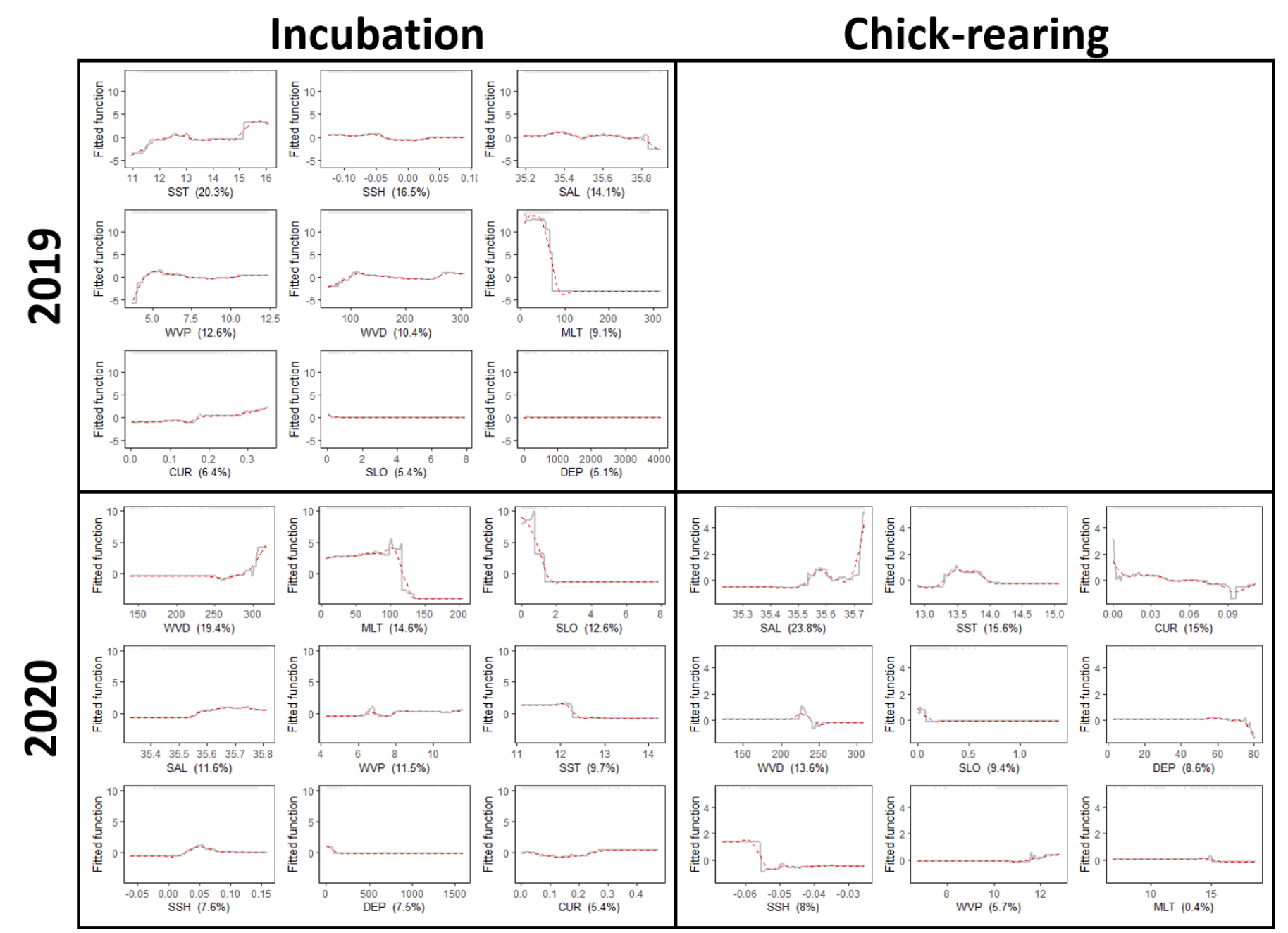

